\title{
Omega 6 fatty acids for the primary prevention of cardiovascular disease (Review)
}

\author{
Al-Khudairy L, Hartley L, Clar C, Flowers N, Hooper L, Rees K
}

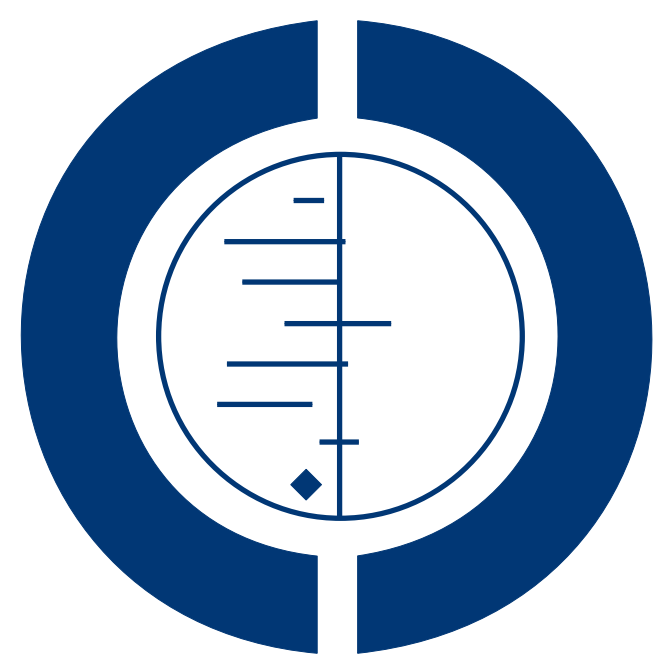

\section{THE COCHRANE COLLABORATION $^{\circledR}$}

This is a reprint of a Cochrane review, prepared and maintained by The Cochrane Collaboration and published in The Cochrane Library 2015, Issue 11

http://www.thecochranelibrary.com

\section{WILEY}

Omega 6 fatty acids for the primary prevention of cardiovascular disease (Review)

Copyright @ 2015 The Cochrane Collaboration. Published by John Wiley \& Sons, Ltd. 
TABLE OF CONTENTS

HEADER . . . . . . . . . . . . . . . . . . . . . . . . . . . . . . . . . . . . . . . . 1

ABSTRACT . . . . . . . . . . . . . . . . . . . . . . . . . . . . . . . . . . . . . . .

PLAIN LANGUAGE SUMMARY . . . . . . . . . . . . . . . . . . . . . . . . . . . . . . . . . . . . 2

BACKGROUND . . . . . . . . . . . . . . . . . . . . . . . . . . . . . . . . . . . . . 3

OBJECTIVES . . . . . . . . . . . . . . . . . . . . . . . . . . . . . . . . . . . . . . . . . . . . . .

METHODS . . . . . . . . . . . . . . . . . . . . . . . . . . . . . . . . . . . . . .

RESULTS . . . . . . . . . . . . . . . . . . . . . . . . . . . . . . . . . . . . . . 8

Figure 1. . . . . . . . . . . . . . . . . . . . . . . . . . . . . . . . . . . . . . 99

Figure 2. . . . . . . . . . . . . . . . . . . . . . . . . . . . . . . . . . . . . . 11

Figure $3 . \quad$. . . . . . . . . . . . . . . . . . . . . . . . . . . . . . . . . . . . . . 412

DISCUSSION . . . . . . . . . . . . . . . . . . . . . . . . . . . . . . . . . . . . . . .

AUTHORS' CONCLUSIONS . . . . . . . . . . . . . . . . . . . . . . . . . . . . . . . . . . . . . .

ACKNOWLEDGEMENTS . . . . . . . . . . . . . . . . . . . . . . . . . . . . . . . . . . . . . . . .

REFERENCES . . . . . . . . . . . . . . . . . . . . . . . . . . . . . . . . . . . . . 16

CHARACTERISTICS OF STUDIES . . . . . . . . . . . . . . . . . . . . . . . . . . . . . . . . . . . . .

DATA AND ANALYSES . . . . . . . . . . . . . . . . . . . . . . . . . . . . . . . . . . . . . 42

Analysis 1.1. Comparison 1 Increased omega 6 versus control, Outcome 1 Systolic blood pressure, change from baseline. 43

Analysis 1.2. Comparison 1 Increased omega 6 versus control, Outcome 2 Diastolic blood pressure, change from baseline. 43

Analysis 1.3. Comparison 1 Increased omega 6 versus control, Outcome 3 Total cholesterol, change from baseline. . 44

Analysis 1.4. Comparison 1 Increased omega 6 versus control, Outcome 4 LDL cholesterol, change from baseline. . 45

Analysis 1.5. Comparison 1 Increased omega 6 versus control, Outcome 5 HDL cholesterol, change from baseline. . 46

Analysis 1.6. Comparison 1 Increased omega 6 versus control, Outcome 6 Triglycerides, change from baseline. . . . 46

Analysis 2.1. Comparison 2 Reduced omega 6 versus control, Outcome 1 Systolic blood pressure, change from baseline. 47

Analysis 2.2. Comparison 2 Reduced omega 6 versus control, Outcome 2 Diastolic blood pressure, change from baseline. 47

Analysis 2.3. Comparison 2 Reduced omega 6 versus control, Outcome 3 Total cholesterol, change from baseline $[\mathrm{mmol} / \mathrm{L}]$.

Analysis 2.4. Comparison 2 Reduced omega 6 versus control, Outcome 4 LDL cholesterol, change from baseline.

Analysis 2.5. Comparison 2 Reduced omega 6 versus control, Outcome 5 HDL cholesterol, change from baseline.

Analysis 2.6. Comparison 2 Reduced omega 6 versus control, Outcome 6 Triglycerides, change from baseline. . . . 50

APPENDICES . . . . . . . . . . . . . . . . . . . . . . . . . . . . . . . . . . . . 50

CONTRIBUTIONS OF AUTHORS . . . . . . . . . . . . . . . . . . . . . . . . . . . . . . . . . . . 56

DECLARATIONS OF INTEREST . . . . . . . . . . . . . . . . . . . . . . . . . . . . . . . . . . . . 56

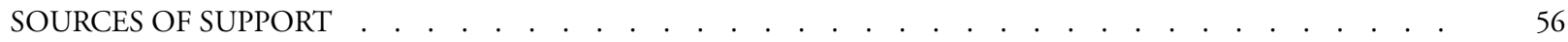

DIFFERENCES BETWEEN PROTOCOL AND REVIEW . . . . . . . . . . . . . . . . . . . . . . . . . . . . . . $\quad 56$

Omega 6 fatty acids for the primary prevention of cardiovascular disease (Review)

Copyright @ 2015 The Cochrane Collaboration. Published by John Wiley \& Sons, Ltd. 


\title{
[Intervention Review] \\ Omega 6 fatty acids for the primary prevention of cardiovascular disease
}

\author{
Lena Al-Khudairy ${ }^{1}$, Louise Hartley ${ }^{1}$, Christine $\mathrm{Clar}^{2}$, Nadine Flowers ${ }^{1}$, Lee Hooper ${ }^{3}$, Karen Rees ${ }^{1}$ \\ ${ }^{1}$ Division of Health Sciences, Warwick Medical School, University of Warwick, Coventry, UK. ${ }^{2}$ Freelance, Berlin, Germany. ${ }^{3}$ Norwich \\ Medical School, University of East Anglia, Norwich, UK
}

Contact address: Karen Rees, Division of Health Sciences, Warwick Medical School, University of Warwick, Coventry, CV4 7AL, UK. Karen.Rees@warwick.ac.uk. rees_karen@yahoo.co.uk.

Editorial group: Cochrane Heart Group.

Publication status and date: New, published in Issue 11, 2015.

Review content assessed as up-to-date: 23 September 2014.

Citation: Al-Khudairy L, Hartley L, Clar C, Flowers N, Hooper L, Rees K. Omega 6 fatty acids for the primary prevention of cardiovascular disease. Cochrane Database of Systematic Reviews 2015, Issue 11. Art. No.: CD011094. DOI: 10.1002/14651858.CD011094.pub2.

Copyright (C) 2015 The Cochrane Collaboration. Published by John Wiley \& Sons, Ltd.

\begin{abstract}
A B S T R A C T

\section{Background}

Omega 6 plays a vital role in many physiological functions but there is controversy concerning its effect on cardiovascular disease (CVD) risk. There is conflicting evidence whether increasing or decreasing omega 6 intake results in beneficial effects.
\end{abstract}

\section{Objectives}

The two primary objectives of this Cochrane review were to determine the effectiveness of:

1. Increasing omega 6 (Linoleic acid (LA), Gamma-linolenic acid (GLA), Dihomo-gamma-linolenic acid (DGLA), Arachidonic acid (AA), or any combination) intake in place of saturated or monounsaturated fats or carbohydrates for the primary prevention of CVD.

2. Decreasing omega 6 (LA, GLA, DGLA, AA, or any combination) intake in place of carbohydrates or protein (or both) for the primary prevention of CVD.

\section{Search methods}

We searched the following electronic databases up to 23 September 2014: the Cochrane Central Register of Controlled Trials (CENTRAL) on the Cochrane Library (Issue 8 of 12, 2014); MEDLINE (Ovid) (1946 to September week 2, 2014); EMBASE Classic and EMBASE (Ovid) (1947 to September 2014); Web of Science Core Collection (Thomson Reuters) (1990 to September 2014); Database of Abstracts of Reviews of Effects (DARE) and Health Technology Assessment Database, and Health Economics Evaluations Database on the Cochrane Library (Issue 3 of 4, 2014). We searched trial registers and reference lists of reviews for further studies. We applied no language restrictions.

\section{Selection criteria}

Randomised controlled trials (RCTs) of interventions stating an intention to increase or decrease omega 6 fatty acids, lasting at least six months, and including healthy adults or adults at high risk of CVD. The comparison group was given no advice, no supplementation, a placebo, a control diet, or continued with their usual diet. The outcomes of interest were CVD clinical events (all-cause mortality, cardiovascular mortality, non-fatal end points) and CVD risk factors (changes in blood pressure, changes in blood lipids, occurrence of type 2 diabetes). We excluded trials involving exercise or multifactorial interventions to avoid confounding.

Omega 6 fatty acids for the primary prevention of cardiovascular disease (Review)

Copyright $\odot 2015$ The Cochrane Collaboration. Published by John Wiley \& Sons, Ltd. 


\section{Data collection and analysis}

Two review authors independently selected trials for inclusion, extracted the data, and assessed the risk of bias in the included trials.

\section{Main results}

We included four RCTs (five papers) that randomised 660 participants. No ongoing trials were identified. All included trials had at least one domain with an unclear risk of bias. There were no RCTs of omega 6 intake reporting CVD clinical events. Three trials investigated the effect of increased omega 6 intake on lipid levels (total cholesterol, low density lipoprotein (LDL-cholesterol), and high density lipoprotein (HDL-cholesterol)), two trials reported triglycerides, and two trials reported blood pressure (diastolic and systolic blood pressure). Two trials, one with two relevant intervention arms, investigated the effect of decreased omega 6 intake on blood pressure parameters and lipid levels (total cholesterol, LDL-cholesterol, and HDL-cholesterol) and one trial reported triglycerides. Our analyses found no statistically significant effects of either increased or decreased omega 6 intake on CVD risk factors.

Two studies were supported by funding from the UK Food Standards Agency and Medical Research Council. One study was supported by Lipid Nutrition, a commercial company in the Netherlands and the Dutch Ministry of Economic Affairs. The final study was supported by grants from the Finnish Food Research Foundation, Finnish Heart Research Foundation, Aarne and Aili Turnen Foundation, and the Research Council for Health, Academy of Finland.

\section{Authors' conclusions}

We found no studies examining the effects of either increased or decreased omega 6 on our primary outcome CVD clinical endpoints and insufficient evidence to show an effect of increased or decreased omega 6 intake on CVD risk factors such as blood lipids and blood pressure. Very few trials were identified with a relatively small number of participants randomised. There is a need for larger well conducted RCTs assessing cardiovascular events as well as cardiovascular risk factors.

\section{PLAIN LANGUAGE SUMMARY}

\section{Omega 6 intake to prevent cardiovascular disease \\ Review question}

We reviewed randomised controlled trials examining the effect of either increased or decreased omega 6 fatty acids for the primary prevention of CVD in healthy adults or adults at high risk of CVD. Four RCTs met the inclusion criteria for this Cochrane review.

\section{Background}

Omega 6 is an essential fatty acid because humans cannot make it in their bodies and must obtain it in their diet. Omega 6 can be obtained from a variety of dietary sources, such as vegetable oil and nuts. Omega 6 fatty acids play a vital role in many physiological functions. They are particularly important for maintaining bone health, regulating metabolism, and in stimulating skin and hair growth. Some evidence suggests that a proportionally higher intake of omega 6 fatty acids along with a low intake of saturated fat is associated with significant reductions in coronary heart disease. In contrast, there is concern that high levels of omega 6 fatty acids may worsen cardiovascular risk. There appears to be inconclusive evidence from observational studies and meta-analyses on the benefits of omega 6 intake on CVD outcomes.

\section{Study characteristics}

The evidence is current to 23 September 2014. In this Cochrane review, four trials met the inclusion criteria and we examined these trials (660 participants) that assessed the effects of either increased or decreased omega 6 intake on lipid levels and blood pressure (major risk factors for cardiovascular disease (CVD)). The diets were followed for 24 weeks. All four trials recruited both male and female participants but varied in the type of participants recruited. Two trials recruited overweight or obese but otherwise healthy adults. One trial recruited older men and post menopausal women, and the remaining trial recruited younger adults with hypercholesterolaemia. Two trials were conducted in the UK, one in the Netherlands, and the remaining trial was conducted in Finland. Trials included a relatively small number of participants and were at some risk of bias.

Two studies were supported by funding from the UK Food Standards Agency and Medical Research Council. One study was supported by Lipid Nutrition, a commercial company in the Netherlands and the Dutch Ministry of Economic Affairs. The final study was supported by grants from the Finnish Food Research Foundation, Finnish Heart Research Foundation, Aarne and Aili Turnen Foundation, and the Research Council for Health, Academy of Finland.

Omega 6 fatty acids for the primary prevention of cardiovascular disease (Review)

Copyright $\odot 2015$ The Cochrane Collaboration. Published by John Wiley \& Sons, Ltd. 


\section{Key results}

No differences in effects of increased or decreased omega 6 intake were seen on blood lipids and blood pressure, but this is based on very few studies. No included trials reported CVD events. There is insufficient evidence to date from randomised controlled trials to recommend increasing or reducing omega 6 for the prevention of CVD.

\section{Quality of the evidence}

There are very few included studies and therefore the results have to be interpreted with caution. Overall we regarded the trials were at unclear risk of bias.

\section{B A C K G R O U N D}

Omega 6 is an essential fatty acid that plays a vital role in many physiological functions but there is controversy concerning its effect on cardiovascular risk. Results from clinical trials and observational studies are inconsistent. There is a need to review the current evidence from randomised controlled trials (RCTs) in this area.

\section{Description of the condition}

Cardiovascular diseases (CVD) are a group of conditions that affect the heart and blood vessels (WHO 2014), and include cerebrovascular disease, coronary heart disease (CHD), and peripheral arterial disease (PAD). One mechanism thought to cause CVD is atherosclerosis, which is where a person's arteries become blocked by plaques or atheromas (NHS 2012). Atherosclerosis can cause CVD when the arteries are completely blocked by a blood clot or when a narrowed artery restricts blood flow limiting the amount of blood and oxygen reaching organs or tissue (BHF 2013). Even though arteries may narrow and become less elastic with age, the process may be accelerated by factors such as smoking, high cholesterol, hypertension, obesity, a sedentary lifestyle, and ethnicity (NHS 2012). Ruptures of unstable plaques may also cause CVD by activating an inflammatory response in the body. This inflammatory response causes the structure of the atherosclerotic plaque to weaken and rupture leading to the formation of blood clots (Spagnoli 2007).

CVDs are the leading causes of death worldwide (WHO 2014), and in 2008 an estimated $30 \%$ of all global deaths were due to CVD (WHO 2014). The burden of CVD also varies substantially between regions (Müller-Nordhorn 2008), for example, death from ischaemic heart disease in France is one-quarter of that of the UK (Law 1999). Furthermore, low- and middle-income countries are disproportionally affected (WHO 2014): in 2001, three-quarters of global deaths from CHD took place in low- and middleincome countries (Gaziano 2010). Gaziano 2010 suggested that this rapid increase in CHD burden is attributable to an increase in life span, socioeconomic changes, and the acquisition of lifestylerelated risk factors.

One key public health priority is targeting modifiable risk factors, including dietary factors, for CVD prevention. Such risk factors are extremely important since their modification has the potential to lower CVD risk, making them a main target for interventions aimed at CVD primary prevention. One major modifiable risk factor is diet and dietary factors, such as a low consumption of fruit and vegetables (Begg 2007), a high intake of saturated fat (Siri-Tarino 2010), and a high consumption of salt (He 2010), which have been found to be associated with CVD risk.

\section{Description of the intervention}

Omega 6 (or n-6) polyunsaturated fatty acids (PUFAs) are characterised by the presence of at least two carbon-carbon double bonds (Harris 2009), as are omega 3 fats. The distinction between omega 6 and omega 3 is based on the position of this double bond from the methyl group end of the fatty acid molecule (Hall 2009; Calder 2013). For omega 6, the double bond pair is sixth from the methyl terminus while for omega 3 the double bond is third (Harris 2009; Calder 2013). Linoleic acid (LA) (18:2n-6), one of the omega 6 fatty acids, is an essential fatty acid because the human body is unable to synthesize it and must be obtained through the diet (Groff 1995). Gamma-linolenic acid (GLA), another omega 6 fatty acid, may become conditionally essential in the event of reduced activity of delta-6-desaturase, which is the enzyme that is necessary for converting LA into GLA (Rincón-Cervera 2009). Other members of the omega 6 group include GLA (18:3n-6), dihomo-gamma-linolenic acid (DGLA) (20:3n-6), and arachidonic acid (AA) (20:4n-6) which can be derived from LA and synthesized in the healthy human body. LA is widely available in the diet from a variety of sources, such as vegetable oils, nut oils, nuts, poultry, meat, egg, milk, margarines, and spreads (Russo 2009). As with omega 3, omega 6 fatty acids play a vital role in many 
physiological functions. They are particularly important for maintaining bone health, regulating metabolism, and in stimulating skin and hair growth. However, evidence on the effect of omega 6 on CVD risk remains controversial. A few studies suggest that a proportionally higher intake of omega 6 fatty acids along with a low intake of saturated fat is associated with significant reductions in CHD (Katan 2009). Indeed, findings from cohort studies have shown omega 6 fatty acids to be inversely associated with cardiovascular death and to be inversely associated with CHD risk (Laaksonen 2005; Oh 2005). Furthermore, studies have shown that omega 6 fatty acids reduce CVD risk factors such as lowdensity lipoprotein cholesterol (LDL-cholesterol) (Hodson 2001; Jakobsen 2009), and blood pressure (Hall 2009). In contrast, there is concern that high levels of dietary of omega 6 will have a pro-inflammatory effect by increasing the production of 2-series prostaglandins and 4-series leukotrienes. Therefore, increased intakes of omega 6 may potentially worsen CVD risk (Russo 2009). However, the American Heart Association recommend consuming around $500 \mathrm{mg} /$ day of omega 3 and $15 \mathrm{mg}$ /day of LA (Harris 2010).

\section{How the intervention might work}

Dietary fat modification can improve CVD risk and risk factors. A meta-analysis of observational studies suggests an inverse relationship between omega 6 intake and CVD risk (Harris 2007). The meta-analysis aimed to evaluate studies assessing the relationship between blood/tissue omega 6 PUFA content and CHD events, and was based on 25 case-control studies with 1998 cases and 6913 controls. Harris 2007 found that LA content of blood and tissues was inversely associated with $\mathrm{CHD}$ risk while $\mathrm{AA}$ was not related to $\mathrm{CHD}$ risk. A recent meta-analysis included only prospective cohort studies that provided multivariate-adjusted risk estimates for dietary LA consumption on CHD endpoints (Farvid 2014). The search identified 13 cohort studies that included 310,602 individuals and 12,479 CHD events, including 5882 CHD deaths. Overall, Farvid 2014 reported a protective effect of LA intake against CHD events and deaths. Replacing saturated fat intake with a 5\% energy increase from LA intake was found to be associated with a $9 \%$ lower risk of CHD events and a 13\% lower risk of CHD deaths (Farvid 2014)

An earlier meta-analysis searched for trials between 1979 to 1999 examining the effect of individual fatty acids on blood lipids. The results included 60 trials randomising 1672 participants and suggested a beneficial effect of PUFAs (including omega 6) on blood lipids (Mensink 2003). This is supported by a meta-analysis of eight RCTs including 13,614 participants which found that replacing saturated fatty acids by increasing PUFA consumption, including omega 6, reduced the occurrence of CHD events (Mozaffarian 2010). A Cochrane review of RCTs investigated the effect of reducing or modifying dietary fats on total CVD mortality and morbidity over at least 6 months. The findings suggest that modification of dietary fat by replacing saturated fats with monounsaturated fatty acids or PUFAs reduces CVD risk (Hooper 2011).

However, there is concern that high levels of omega 6 fatty acids compared with omega 3 fatty acids in the diet increases the production of 2-series prostaglandins and 4-series leukotrienes compared with 3-series prostaglandins and 5-series leukotrienes. As the 2-series prostaglandins and 4-series leukotrienes exert a more potent pro-inflammatory effect, omega 6 fatty acids may theoretically worsen cardiovascular risk (Russo 2009). This relationship is disputed, but has led to the concept that the ratio between omega 6 and omega 3 fatty acids may be crucial, rather than absolute intakes of either omega 6 or omega 3 fatty acids. In addition, there is concern that highly unsaturated fatty acids such as AA may increase the susceptibility of lipoproteins such as LDL and very-low-density lipoproteins (VLDL) to oxidation, making them more atherogenic (Russo 2009).

A number of studies have found no association between omega 6 intakes and risk of CVD. Earlier prospective cohort studies found no association between dietary intakes of omega 6 fatty acids and stroke (He 2003), CHD (McGee 1984; Pietinen 1997) and CHD mortality (Esrey 1996). The Sydney Diet Heart Study, a RCT of 458 men aged between 30 to 59 years with a recent coronary event, reported increased rates of death from all causes, CHD, and CVD when substituting dietary linoleic acid in place of saturated fats (Ramsden 2013). A systematic review of 36 reviewed and peerreviewed studies reported no effect of LA dietary modification intake on changes in AA levels in plasma, serum or erythrocytes in adults (Whelan 2011). Chowdhury 2014, a recent systematic review of prospective, observational studies and RCTs, reported non-significant associations between omega- 6 fatty acids supplementation and coronary disease or outcomes.

\section{Why it is important to do this review}

There appears to be inconclusive evidence from observational studies and meta-analyses on the benefit of omega 6 intake on CVD outcomes. Therefore, an up-to-date systematic review is required to clarify the association between CVD risk and omega 6 intake. This can then provide guidance for national and international agencies, practitioners, and members of the public.

A previous systematic review of RCTs has examined the effect of change in dietary fat intake (including LA) on CVD morbidity in adults with or without CVD (Hooper 2011). Mozaffarian 2010, another systematic review, examined increased total or omega 6 PUFAs in adults with or without CVD events. A recent systematic review summarised the association between fatty acids (including omega 6) and coronary disease. The RCTs of the review included interventions that recorded coronary outcomes as an end point of interest and were conducted predominantly in those with established CVD (Chowdhury 2014). Therefore previous reviews have not explicitly examined increased or decreased omega 6 intake for the primary prevention of CVD (Mozaffarian 2010; Hooper 
2011; Chowdhury 2014). With this in mind, we undertook this Cochrane review to assess the current evidence. We included RCTs that stated an intention to increase or decrease omega 6 fats by following dietary advice, omega 6 supplementation, or a provided diet. We examined the effects over longer time periods (at least six months) as these are most relevant for public health interventions.

\section{O B J E C T IVES}

The two primary objectives of this Cochrane review were to determine the effectiveness of:

1. Increasing omega 6 (LA, GLA, DGLA, AA, or any combination) intake in place of saturated or monounsaturated fats or carbohydrates for the primary prevention of CVD.

2. Decreasing omega 6 (LA, GLA, DGLA, AA, or any combination) intake in place of carbohydrates or protein (or both) for the primary prevention of CVD.

\section{METHODS}

\section{Criteria for considering studies for this review}

\section{Types of studies}

We included RCTs. We included trials reported as full-text articles, as abstracts only, and unpublished data.

\section{Types of participants}

Healthy adults (aged $\geq 18$ years old) from the general worldwide population and adults at moderate to high risk of CVD. As this review focused on the primary prevention of CVD, we excluded people who had experienced a myocardial infarction (MI), stroke, revascularization procedure (coronary artery bypass grafting $(\mathrm{CABG})$, or percutaneous transluminal coronary angioplasty (PTCA)), people with angina, and people with angiographically defined CHD. We also excluded people with type 2 diabetes, as, while type 2 diabetes is a risk factor for CVD, interventions targeting this condition are covered by the Cochrane Metabolic and Endocrine Disorders Group.

\section{Types of interventions}

We included all RCTs of interventions that stated an intention to increase or decrease omega 6 fatty acids. Interventions had to involve dietary advice, supplementation, or provide a diet where omega 6 fatty acids were either increased or decreased. Studies could include any type of omega 6 or combination of omega 6 fatty acids. We considered trials involving an increase or decrease in omega 6 fatty acids with energy replacement by carbohydrates, omega 3, omega 9, saturated fats, protein, alcohol, or monounsaturated fats, and included studies with additional dietary interventions. We excluded trials with other major concomitant interventions, such as exercise or other multiple lifestyle interventions to avoid confounding.

We also focused on follow-up periods of six months (24 weeks) or longer. Follow-up was considered to be the time elapsed since the start of the intervention and, therefore, we excluded any trials with an intervention period of less than six months as longer term studies examine sustained changes which are more relevant for public health interventions. For the control group, we considered trials where the comparison group was given no advice, no supplementation, a placebo, a control diet, or continued with their usual diet. This included dietary intakes that represent the typical dietary composition for that setting.

\section{Types of outcome measures}

\section{Primary outcomes}

1. All-cause mortality.

2. Cardiovascular mortality.

3. Non-fatal end points such as MI, CABG, PTCA, angina, angiographically defined $\mathrm{CHD}$, stroke, carotid endarterectomy, and PAD.

\section{Secondary outcomes}

1. Changes in blood pressure (systolic and diastolic blood pressure) and blood lipids (total cholesterol, HCL cholesterol, LDL cholesterol, triglycerides).

2. Occurrence of type 2 diabetes as a major CVD risk factor.

3. Adverse effects (as defined by the authors of the included trials).

\section{Search methods for identification of studies}

\section{Electronic searches}

We identified trials through systematic searches of the following bibliographic databases:

- Cochrane Central Register of Controlled Trials

(CENTRAL, the Cochrane Library) (Issue 8 of 12, 2014).

- MEDLINE (Ovid) (1946 to September week 2, 2014).

- EMBASE Classic + EMBASE (Ovid) (1947 to September 2014). 
- Web of Science Core Collection (Thomson Reuters) (1990 to September 2014).

- Database of Abstracts of Reviews of Effects (DARE), Health Technology Assessment Database, and Health Economics Evaluations Database on the Cochrane Library (Issue 3 of 4, 2014).

We adapted the preliminary search strategy for MEDLINE (Ovid) for use in the other databases (Appendix 1). We also applied the Cochrane sensitivity-maximising RCT filter (Lefebvre 2011) to MEDLINE (Ovid) and adaptations of it to the other databases, except CENTRAL.

We searched all databases from their inception to the dates indicated, and imposed no restriction on language of publication.

\section{Searching other resources}

We checked reference lists of all primary studies and review articles for additional references.

We searched the clinical trial registers on the 18 January 2015 (Appendix 1). We also conducted a search of ClinicalTrials.gov ( www.clinicaltrials.gov), metaRegister of controlled trials (mRCT) (www.controlled-trials.com/mrct), and the World Health Organization (WHO) International Clinical Trials Registry Platform (ICTRP) Search Portal (apps.who.int/trialsearch/).

We contacted trial authors when necessary for any additional information.

\section{Data collection and analysis}

\section{Selection of studies}

Two review authors (LH, CC or NF) independently screened titles and abstracts for inclusion and coded them as 'retrieve' (eligible or potentially eligible/unclear) or 'do not retrieve'. If there were any disagreements, we asked a third review author to arbitrate (KR). We retrieved the full-text study reports/publication and two authors (LH, CC) independently screened the full-text and identified studies for inclusion, and identified and recorded reasons for exclusion of the ineligible studies. We resolved any disagreements through discussion or, if required, we consulted a third review author (KR). We identified and excluded duplicates and collated multiple reports of the same study so that each study, rather than each report, was the unit of interest in the review. We recorded the selection process in sufficient detail to complete a PRISMA flow diagram and 'Characteristics of excluded studies' table.

\section{Data extraction and management}

We used a data collection form for trial characteristics and outcome data that had been piloted on at least one trial included in the review. Two review authors (LA, LH or CC) extracted the following study characteristics from included studies:

1. Methods: trial design, total duration of trial, details of any 'run-in' period, number of trial centres and location, trial setting, withdrawals, and date of trial.

2. Participants: number, mean age, age range, gender, severity of condition, diagnostic criteria, smoking history, inclusion criteria, and exclusion criteria.

3. Interventions: intervention, comparison, concomitant medications, and excluded medications.

4. For intervention and control (during intervention): the percentage of energy from omega 3, omega 6 , omega 9 , saturated fats, monounsaturated fats, carbohydrates (refined and unrefined if possible), alcohol, protein, and omega 6/omega 3 ratio.

5. Outcomes: primary and secondary outcomes specified and collected, and time points reported.

6. Notes: funding for trial, and notable conflicts of interest of trial authors.

Two review authors (LA, LH or CC) independently extracted outcome data from included trials. We resolved disagreements by consensus or by involving a third review author (KR). One review author (LH) transferred data into RevMan 2014. We doublechecked that data were entered correctly by comparing the data presented in the systematic review with the data in the trial reports. A second review author (LA) spot-checked trial characteristics for accuracy against the trial reports.

\section{Assessment of risk of bias in included studies}

Two review authors (LA, LH or CC) independently assessed risk of bias for each included trial using the criteria outlined in the Cochrane Handbook for Systematic Reviews of Interventions (Higgins 2011). We resolved any disagreements by discussion or by involving another review author (KR). We assessed the risk of bias according to the following domains:

1. Random sequence generation.

2. Allocation concealment.

3. Blinding of participants and personnel.

4. Blinding of outcome assessment.

5. Incomplete outcome data.

6. Selective outcome reporting.

7. Other bias (e.g. industry funding).

We graded each potential source of bias as either 'high', 'low', or 'unclear' and provided a quote from the study report together with a justification for our judgement in the 'Risk of bias' table. We summarised the 'Risk of bias' judgements across different studies for each of the domains listed. Where information on risk of bias related to unpublished data or correspondence with a trial author, we noted this in the 'Risk of bias' table.

When considering treatment effects, we took into account the risk of bias for the studies that contributed to that outcome. 


\section{Assessment of bias in conducting the systematic review}

We conducted this Cochrane review according to its published protocol, Hartley 2014, and reported any deviations from it in the 'Differences between protocol and review' section.

\section{Measures of treatment effect}

We analysed dichotomous data as risk ratios (RRs) with 95\% confidence intervals (CIs) and continuous data as mean difference (MD) or standardised mean difference (SMD) with 95\% CIs. We entered data presented as a scale with a consistent direction of effect, with the exception of HDL cholesterol where an increase in this outcome is a positive finding.

We intended to narratively describe skewed data reported as medians and interquartile ranges but this did not apply to any of the included trials.

\section{Unit of analysis issues}

\section{Studies with multiple intervention groups}

Data for the control group have been used for each intervention group comparison. We reduced the weight assigned to the control group by dividing the control group $\mathrm{N}$ by the number of intervention groups analysed.

\section{Cluster-RCTs}

We intended to analyse cluster-RCTs using the unit of randomisation (cluster) as the number of observations, and use individual level means and SDs adjusted for clustering together with the number of clusters in the denominator, where needed, in order to weight the trials appropriately. However we did not find any cluster-RCTs that met the inclusion criteria.

\section{Cross-over studies}

For included cross-over studies we only used the first period.

\section{Dealing with missing data}

We contacted trial authors or study sponsors in order to verify key study characteristics and obtain missing numerical outcome data where possible (e.g. when a study is identified as abstract only). Where this was not possible, and the missing data were thought to introduce serious bias, we explored the impact of including such studies in the overall assessment of results using a sensitivity analysis. Where papers did not report results as change from baseline we calculated this and for the SD differences followed the methods presented in the Cochrane Handbook for Systematic Reviews of
Interventions for imputing these (16.1.3.2 Imputing standard deviations for changes from baseline, Higgins 2011), and assumed a correlation of 0.5 between baseline and follow-up measures as suggested by Follman 1992 .

\section{Assessment of heterogeneity}

We used the $\mathrm{I}^{2}$ statistic to measure heterogeneity among the trials in each analysis. If we identified substantial heterogeneity (heterogeneity of greater than 50\%), we reported it and explored possible causes by pre-specified subgroup analysis.

\section{Assessment of reporting biases}

We were unable to pool more than 10 trials and so did not use a funnel plot to explore possible small-study biases for the primary outcomes.

\section{Data synthesis}

We conducted statistical analysis using RevMan 2014. Continuous data were entered as the difference in means and SDs between baseline and follow-up. In the absence of substantial heterogeneity (greater than 50\%) and if there was a sufficient number of trials, we combined the results using a fixed-effect model.

\section{Subgroup analysis and investigation of heterogeneity}

We planned to carry out the following subgroup analyses but there were an insufficient number of trials included to do this:

1. Omega 6 alone versus omega 6 plus other dietary components.

2. Baseline risk.

3. Increase or decrease in omega 6.

4. Omega 6/omega 3 ratio.

5. Age.

6. Sex.

We also planned to assess the treatment effects of omega 6 according to energy replacement (e.g. by what omega 6 is replacing or, for a decrease in omega 6 , what is replacing omega 6 ), including:

1. Carbohydrates.

2. Saturated fats.

3. Omega 3 fatty acids.

4. Omega 9 fatty acids.

5. Protein.

6. Alcohol.

7. Monounsaturated fats.

We intended to further explore the effects of the above different energy replacements by using meta-regression on our primary outcomes. However, none of the included trials reported our primary outcomes and there was an insufficient number of included trials reporting our secondary outcomes to conduct these analyses. 
We intended to use the formal test for subgroup interactions in RevMan 2014.

\section{Sensitivity analysis}

We planned to carry out the following sensitivity analyses but there were an insufficient number of trials included to do this:

1. Only including studies at low risk of bias (assessed using the Cochrane 'Risk of bias' assessment tool).

2. Only including studies where the alteration in omega 6

(and its energy replacement) is the only dietary intervention.

\section{Reaching conclusions}

We based our conclusions only on findings from the quantitative or narrative synthesis of included studies for this Cochrane review. We avoided making recommendations for practice and our implications for research suggest priorities for future research and outline what the remaining uncertainties are in the area.

\section{RE S U L T S}

\section{Description of studies}

\section{Results of the search}

The searches generated 6921 hits and 3999 after de-duplication. After screening the titles and abstracts, we identified 152 papers for formal inclusion and exclusion. Of these, four RCTs (five papers) met the inclusion criteria, and one of the four RCTs had two relevant intervention arms (Moore 2006 High LA; Moore 2006 Low LA). We did not identify any ongoing trials. We have presented details of the flow of studies in Figure 1. 
Figure I. Study flow diagram.

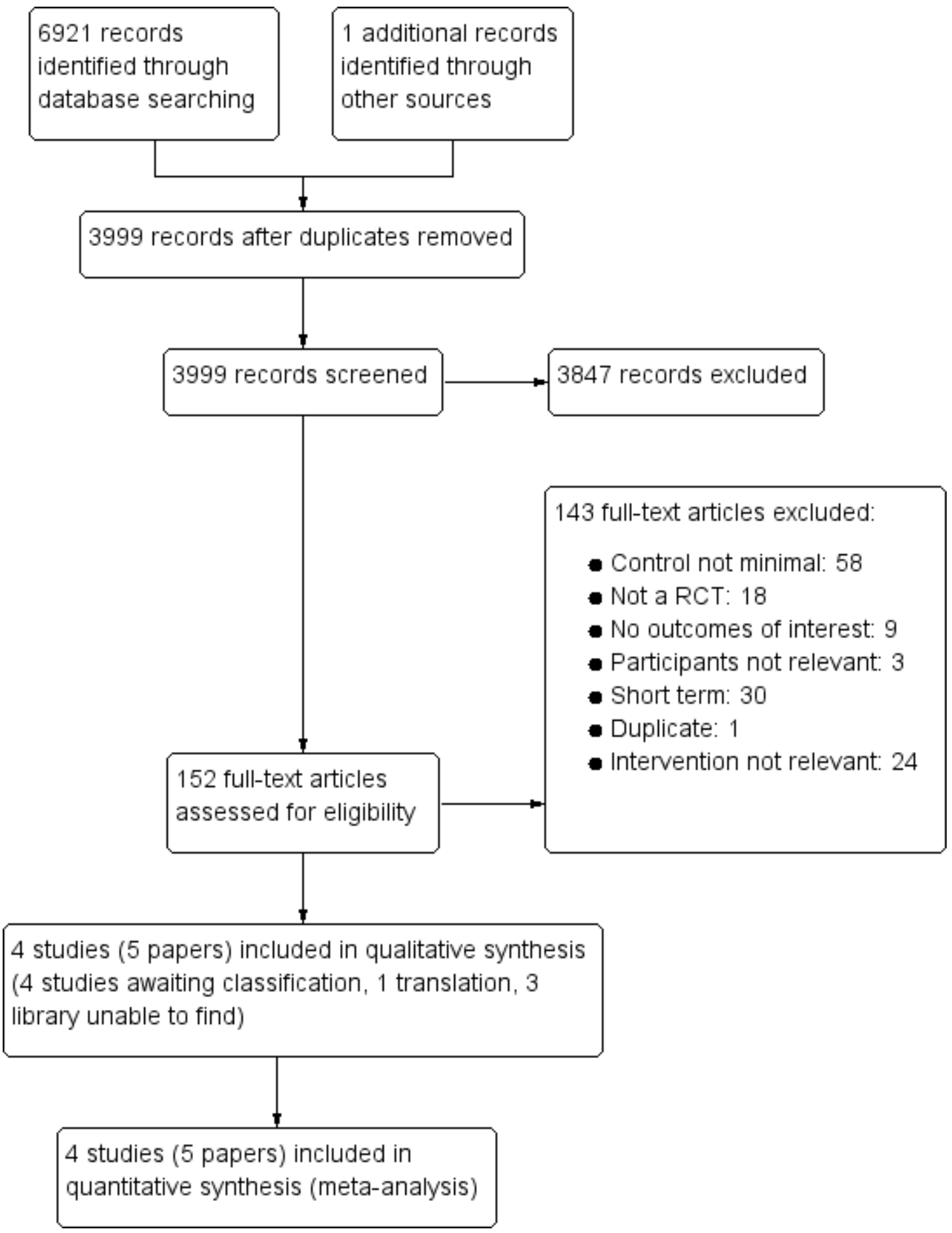




\section{Included studies}

The details of the methods, participants, intervention, comparison group, and outcome measures for each of the included trials are shown in the 'Characteristics of included studies' table. Four trials, including 664 participants, met the inclusion criteria.

All four trials recruited both male and female participants (Sarkkinen 1998; Moore 2006 High LA; Moore 2006 Low LA; OPTILIP 2006; Sluijs 2010). The trials varied in the participants recruited. Two trials recruited overweight or obese but otherwise healthy adults aged 35 to 65 years (Moore 2006 High LA; Moore 2006 Low LA), and 40 to 70 years (Sluijs 2010). One trial recruited older men and post menopausal women aged 45 to 70 years (OPTILIP 2006). One trial recruited younger adults aged 23 to 58 years with hypercholesterolaemia (Sarkkinen 1998).

Two trials were conducted in the UK (Moore 2006 High LA; Moore 2006 Low LA; OPTILIP 2006), one in the Netherlands (Sluijs 2010), whilst the remaining trial was conducted in Finland (Sarkkinen 1998).

All included trials had the same duration of follow-up (24 weeks) (Sarkkinen 1998; Moore 2006 High LA; Moore 2006 Low LA; OPTILIP 2006; Sluijs 2010).

Three trials reported on the effects of increasing omega 6 intake, and two trials reported on decreasing omega 6 intake.

Three trials increased omega 6 intake and provided high LA oils and spreads throughout the duration of the study (Sarkkinen 1998; Moore 2006 High LA; Sluijs 2010) but the LA content varied across studies.

The high LA intervention arm of the Moore 2006 trial, Moore 2006 High LA, increased the omega 6:omega 3 ratio by providing sunflower fats (LA: $\alpha$-linolenic acid (LNA) was 27:1 for sunflower spreads and 63:0.1 for sunflower oil). This trial aimed to maintain a low omega 3 intake hence participants were provided with white fish but the portions were not reported. The control group of Moore 2006 High LA received no intervention.

The third trial increased omega 6 intake by providing detailed written instructions of food consumption, typically consumed in a Finnish diet, tailored to participants own energy levels. In the reduced-fat sunflower oil-enriched intervention diet, the goal was to consume $30 \%$ of energy from fat $(10 \%$ saturated fat, $10 \%$ monosaturated fat, $10 \%$ polyunsaturated fat), $15 \%$ of energy from protein, $55 \%$ of energy from carbohydrate, and 15 to $20 \mathrm{~g}$ of fibre per day. Additionally, sunflower oil and margarine were provided throughout the study. The content of LA was not provided but the mean consumption throughout the study was reported $(13.3 \pm 3.5$ $\mathrm{g}$ /day). In the high fat, saturated fat-enriched control diet typical of the normal Finnish diet, participants received detailed written instructions on diet at their own energy level. However, the goal was to consume $38 \%$ of energy from fat (18\% saturated fat, $15 \%$ monosaturated fat, $5 \%$ polyunsaturated fat), $15 \%$ of energy from protein, $47 \%$ of energy from carbohydrate, and 15 to $20 \mathrm{~g}$ of fibre per day. Butter and a small amount of low-erucic acid rapeseed oil were provided (Sarkkinen 1998).

Another trial increased omega 6 by using cis-9,trans-11 conjugated linoleic acid (c9,t11 CLA). The c9, t11 CLA oil was manufactured from safflower oil and four capsules of $1 \mathrm{~g}$ oil each were taken daily. Placebo capsules contained an equal amount of fat and were composed of a blend of palm oil ( $80 \%)$ and soybean oil (20\%), which resembles the average fatty acid composition of the fat consumed by a Western population (Sluijs 2010).

The low LA intervention arm of the Moore 2006 trial, Moore 2006 Low LA, decreased the omega 6:omega 3 ratio by providing rapeseed fats (LA:LNA was 3:1 for rapeseed spread, and 2:1 for rapeseed oil). The trial aimed to maintain a low omega 3 intake hence participants were provided white fish but the portions were not reported. The control group of Moore 2006 Low LA received no intervention.

The second trial, OPTILIP 2006, decreased omega 6 intake by providing oils and spreads for the duration of the study. The spreads contained $4.7 \mathrm{~g} / 100 \mathrm{~g}$ of LA and $0.8 \mathrm{~g} / 100 \mathrm{~g}$ of ALA. The LA and ALA contents of rapeseed (canola) oil were $19.7 \mathrm{~g}$ and $8.9 \mathrm{~g} / 100 \mathrm{~g}$ respectively. Participants were also provided with two small cans of tuna/week, the tuna was canned in high linoleic sunflower oil. The diet was designed to keep the intake of saturated and monounsaturated fatty acids constant and to provide $-6 \%$ of energy from PUFAs. The control had a higher omega 6 content that was similar to the household food consumption as stated by the authors. In the control diet, the LA and ALA contents of the spreads were $39.6 \mathrm{~g}$ and $0.5 \mathrm{~g} / 100 \mathrm{~g}$. The LA and ALA contents of high-oleic sunflower oil were $10.6 \mathrm{~g}$ and $0.3 \mathrm{~g} / 100 \mathrm{~g}$. Participants in the control group were provided with two small cans of tuna/ week, and the tuna was canned in olive oil (OPTILIP 2006).

Four trials are awaiting assessment and we have presented details in the 'Characteristics of studies awaiting classification' section. One trial with two relevant intervention arms needs to be translated from Norwegian (Natvig 1967 High LA; Natvig 1967 Low LA). The English abstract is presented in the 'Characteristics of studies awaiting classification' table. This is a large trial but it was conducted in the 1960s and there are insufficient details in the abstract to determine the conduct of the trial (methods of randomisation and allocation) and outcome data. The library were unable to provide the full text record for one trial with a relevant intervention arm (Nordoy 1981). We have presented the English abstract in the 'Characteristics of studies awaiting classification' table. This is a very small trial with only 10 participants and there are insufficient details in the abstract to determine the conduct of the trial (study design, follow-up time, and outcomes measured). For the other two studies, no abstract was available and the library 
was unable to provide us with full text records (Singer 1991; Ryu 1999).

We did not identify any ongoing trials.

\section{Excluded studies}

We have presented details and reasons for exclusion of the studies that most closely missed the inclusion criteria in the 'Characteristics of excluded studies' table. The most common reasons for exclusion of studies included the control group did not receive a minimal intervention or no intervention, studies included alternative designs (not RCTs), and studies were short-term (< six months follow-up) (see Figure 1).

\section{Risk of bias in included studies}

We have provided details regarding the risk of bias judgements for the included trials in the 'Risk of bias' tables in the 'Characteristics of included studies' section. Also, we have presented 'Risk of bias' summaries in Figure 2 and Figure 3. We will include a 'Summary of findings' table and GRADE assessment in an update of this Cochrane review.

Figure 2. 'Risk of bias' graph: review authors' judgements about each 'Risk of bias' item presented as percentages across all included studies.

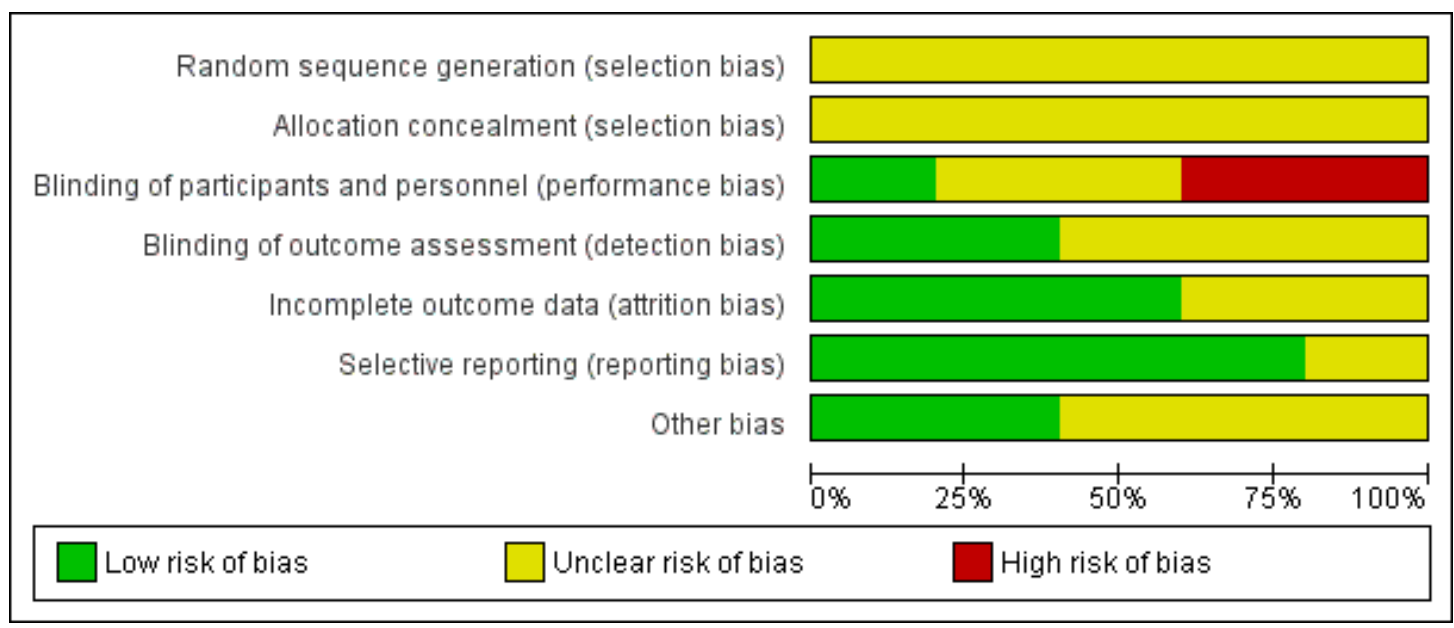


Figure 3. 'Risk of bias' summary: review authors' judgements about each 'Risk of bias' item for each included study.

\begin{tabular}{|c|c|c|c|c|c|c|c|}
\hline & 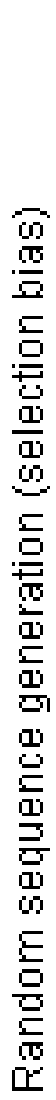 & 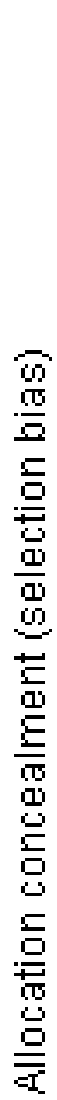 & 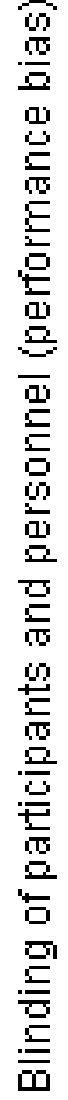 & 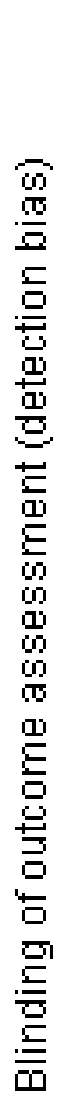 & 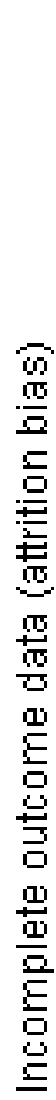 & 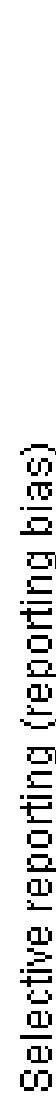 & 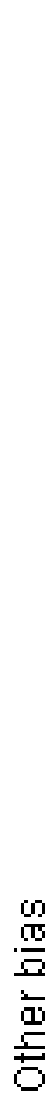 \\
\hline \multicolumn{8}{|l|}{ Moore 2006 High LA } \\
\hline \multicolumn{8}{|l|}{ Woore 2006 Low LA } \\
\hline OPTILIP 2006 & $?$ & $?$ & $?$ & $?$ & $?$ & & $?$ \\
\hline Sarkkinen 1998 & $?$ & $?$ & $?$ & $?$ & $?$ & & $?$ \\
\hline Sluijs 2010 & $?$ & $?$ & & $?$ & $t$ & $?$ & $?$ \\
\hline
\end{tabular}




\section{Allocation}

No details were provided for the method of random sequence generation and allocation concealment in all included trials. We judged this to be at unclear risk of bias for all included trials.

\section{Blinding}

One trial reported that blinding of participants was not carried out and was judged to be at high risk of performance bias (Moore 2006 High LA; Moore 2006 Low LA). One trial reported that the investigators were unaware of treatment allocations for the trial duration and was judged to be at low risk of performance bias (Sluijs 2010). One trial, Moore 2006 High LA; Moore 2006 Low LA, clearly reported that outcome assessment personnel involved in the study were blinded to the randomisation and was judged at low risk of detection bias. One trial did not report details on blinding (OPTILIP 2006) and was judged to be at unclear risk of bias for both domains. One trial, Sarkkinen 1998, reported that spreads were provided on a single-blind basis but no further details were provided and this was judged as unclear risk of bias for both performance and detection.

\section{Incomplete outcome data}

Two trials (Moore 2006 High LA; Moore 2006 Low LA; Sluijs 2010) were judged to be at low risk of bias as the number of dropouts was clearly presented for each study arm at each stage of the trial. Two trials reported the number of drop-outs for the overall sample but not per study arm and were judged to be at unclear risk of bias (Sarkkinen 1998; OPTILIP 2006). None of the included studies used an intention-to-treat (ITT) analysis.

\section{Selective reporting}

All trials presented outcomes as reported and were judged to be at low risk of bias.

\section{Other potential sources of bias}

One trial, Moore 2006 High LA; Moore 2006 Low LA, was judged to be at low risk of bias as they clearly report power calculations, comparability of baseline characteristics and there was no industry funding. One trial was judged to be at unclear risk as it was not underpowered, baseline characteristics were similar between the two groups, but the study was partially funded by commercial funds (Sluijs 2010). Two trials were judged to be at unclear risk of bias because of insufficient information provided (Sarkkinen 1998; OPTILIP 2006).

\section{Effects of interventions}

\section{Increased omega 6}

\section{Primary outcomes}

None of the included trials reported data for our primary outcomes (all-cause mortality, cardiovascular mortality, or non-fatal end points such as MI, CABG, PTCA, angina, angiographically defined CHD, stroke, carotid endarterectomy, and PAD) (Sarkkinen 1998; Moore 2006 High LA; OPTILIP 2006; Sluijs 2010).

\section{Secondary outcomes}

\section{Blood pressure}

Two trials of increased omega 6 intake reported data on systolic (SBP) and diastolic (DBP) blood pressure. There was no significant heterogeneity $\left(\mathrm{I}^{2}\right.$ statistic $\left.=0 \%\right)$ for either SBP or DBP and results are dominated by one larger trial (Sluijs 2010, 346 participants randomised). The pooled analysis of two trials showed no statistically significant effect of increased omega 6 intake on either SBP (MD -0.79, 95\% CI -3.0, 1.41; two trials, 387 participants; Analysis 1.1) or DBP (MD -0.02, 95\% CI -1.35 to 1.32 ; two trials, 387 participants; Analysis 1.2).

\section{Lipid levels}

Three trials reported the effect of increased omega 6 intake on lipid levels (Sarkkinen 1998; Moore 2006 High LA; Sluijs 2010). For total cholesterol, there was significant heterogeneity ( $\mathrm{I}^{2}$ statistic $=51 \%$ ) and results were dominated by one larger trial (Sluijs 2010). The pooled analysis of three trials showed no statistically significant effect of increased omega 6 intake on total cholesterol (MD 0.02, 95\% CI -0.13 to 0.18; three trials, 460 participants; Analysis 1.3).

For LDL-cholesterol, there was moderate heterogeneity (I² statistic $=38 \%$ ) and results were dominated by one larger trial (Sluijs 2010). The pooled analysis of the three trials showed no statistically significant effect of increased omega 6 intake on LDL-cholesterol (MD -0.01, 95\% CI -0.14 to 0.12 ; three trials, 460 participants; Analysis 1.4).

For HDL-cholesterol, there was no heterogeneity ( $\mathrm{I}^{2}$ statistic $=$ $0 \%$ ) and results were dominated by one larger trial (Sluijs 2010). The pooled analysis of the three trials showed no statistically significant effect of increased omega 6 intake on HDL-cholesterol 
(MD 0.01, 95\% CI -0.04 to 0.06; three trials, 460 participants; Analysis 1.5).

For triglycerides, there was no heterogeneity $\left(\mathrm{I}^{2}\right.$ statistic $\left.=0 \%\right)$ and results were dominated by one larger trial (Sluijs 2010). The pooled analysis of the two trials showed no statistically significant effect of increased omega 6 intake on triglycerides levels (MD 0.03, 95\% CI -0.07 to 0.12; two trials, 419 participants; Analysis 1.6).

\section{Occurrence of type 2 diabetes as a major CVD risk factor}

None of the included trials reported data on the occurrence of type 2 diabetes.

\section{Adverse effects}

None of the included studies reported adverse effects.

\section{Reduced omega 6}

\section{Primary outcomes}

Two trials reported the effects of decreasing omega 6 and did not report data for our primary outcomes (all-cause mortality, cardiovascular mortality, or non-fatal end points such as MI, CABG, PTCA, angina, angiographically defined CHD, stroke, carotid endarterectomy, and PAD) (Moore 2006 Low LA; OPTILIP 2006).

\section{Secondary outcomes}

\section{Blood pressure}

One trial examined effects of decreasing omega 6 on SBP and DBP (Moore 2006 Low LA). This single trial reported no statistically significant effect of reduced omega 6 intake on either SBP (MD $0.80,95 \%$ CI -14.34 to 12.74 ; Analysis 2.1) or DBP (MD 0.60, 95\% CI -6.82 to 8.02 ; Analysis 2.2).

\section{Lipid levels}

Two trials reported the effect of decreased omega 6 intake on lipid levels (Moore 2006 Low LA; OPTILIP 2006). One of the trials, OPTILIP 2006, included participants on lipid lowering drugs.

For total cholesterol, there was no heterogeneity $\left(\mathrm{I}^{2}\right.$ statistic $\left.=0 \%\right)$ and the pooled analysis of the two trials showed no statistically significant effect of decreased omega 6 intake on total cholesterol levels (MD 0.06, 95\% -0.31 to 0.43; two trials, 114 participants; Analysis 2.3).

For LDL-cholesterol, there was no heterogeneity $\left(\mathrm{I}^{2}\right.$ statistic $\left.=0 \%\right)$ and the pooled analysis of the two trials showed no statistically significant effect of decreased omega 6 intake on LDL-cholesterol levels (MD -0.04, 95\% CI -0.36 to 0.29; two trials, 114 participants; Analysis 2.4).

For HDL-cholesterol, there was no heterogeneity $\left(\mathrm{I}^{2}\right.$ statistic $=$ $0 \%)$ and the pooled analysis of the two trials showed no statistically significant effect of decreased omega 6 intake on HDLcholesterol levels (MD -0.02, 95\% CI -0.16 to 0.12 ; two trials, 114 participants; Analysis 2.5).

One trial reported the effect of reducing omega 6 on triglycerides levels (OPTILIP 2006). The single trial reported no statistically significant effect of reduced omega 6 intake on triglycerides (MD $0.13,95 \%$ CI -0.11 to 0.37 ; Analysis 2.6).

\section{Occurrence of type $\mathbf{2}$ diabetes as a major CVD risk factor}

None of the included trials reported data on the occurrence of type 2 diabetes.

\section{Adverse effects}

None of the included trials reported adverse effects.

\section{DISCUSSION}

\section{Summary of main results}

This Cochrane review included four trials (five papers) that randomised 660 participants. We did not identify any ongoing trials. There were no RCTs on omega 6 intake reporting CVD clinical events. Three trials investigated the effect of increased omega 6 intake on lipid levels (total cholesterol, LDL-cholesterol, and HDLcholesterol) (Moore 2006 High LA; Sarkkinen 1998; Sluijs 2010), two trials reported triglycerides (Sarkkinen 1998; Sluijs 2010), and two trials reported blood pressure (diastolic and systolic blood pressure) (Moore 2006 High LA; Sluijs 2010). One trial, with two relevant intervention arms, investigated the effect of increased and decreased omega 6 intake on blood pressure parameters (Moore 2006 High LA; Moore 2006 Low LA). Two trials investigated the effect of decreased omega 6 intake on lipid levels (total cholesterol, LDL-cholesterol, and HDL-cholesterol) (Moore 2006 Low LA; OPTILIP 2006) and one trial reported triglycerides (OPTILIP 2006). All included trials were at unclear risk of bias for most risk of bias domains, but all four trials had a low risk of selective reporting bias.

Overall, our analyses found no statistically significant effects of increased omega 6 intake on lipid levels in three trials measuring these, or blood pressure in the two trials reporting this, but results are restricted to very few relatively small trials and are therefore limited. Two trials reported the effects of decreasing omega 6 on blood lipids and found no effects of the intervention. Only one 
trial reported the effect of decreasing omega 6 on blood pressure and found no effect of the intervention.

\section{Overall completeness and applicability of evidence}

Very few studies met the inclusion criteria and results are therefore extremely limited. None of the included trials reported our primary outcomes but trials were relatively small and short term. No conclusions can be drawn as to the effects of increasing or decreasing omega 6 on cardiovascular risk factors. Adverse events were not reported in any of the included trials.

Although all included trials provided oils/spreads/capsules to change omega 6 intake, the increased or decreased omega 6 : omega 3 ratio varied across studies. One study did not report the LA amount but provided the mean values of LA consumption (Sarkkinen 1998). This trial included foods typically consumed in the Finnish diet but no further details were provided. Food items rich in omega 6 , such as poultry, meat, egg, milk, and nuts, were not used to increase omega 6 intakes in any of the included trials hence it is unclear how trial results translate to real life scenarios. All trials included several study arms, some of which were irrelevant to this review, and therefore the number of randomised participants for this review dropped substantially.

\section{Quality of the evidence}

Unclear risk of bias in most 'Risk of bias' domains of the four included trials makes overall interpretation of the data difficult. Sample sizes were small and durations of follow-up did not exceed 24 weeks. None of the included trials used ITT analysis. We will include a 'Summary of findings' table and perform GRADE assessments in an update of this Cochrane review.

\section{Potential biases in the review process}

We performed a comprehensive search across major databases for interventions involving increased or decreased omega 6 intake for this review. In addition, we checked reference lists of all primary studies and review articles for additional references. Two review authors independently performed all screening, inclusion and exclusion determination, and data extraction.

Our strict inclusion criteria limited the number of studies available for inclusion in this review. We only considered trials of follow-up periods of six months (24 weeks) or more. Follow-up was considered to be the time elapsed since the start of the intervention and, therefore, we excluded any trials with an intervention period of less than six months. Whilst trials with longer term follow-up are more relevant for public health interventions, this restriction has substantially reduced the number of eligible studies for inclusion.

\section{Agreements and disagreements with other studies or reviews}

A previous review of controlled trials found that replacement of carbohydrates with PUFAs (which the authors considered may be equal omega 6) was found to significantly reduce total cholesterol levels (estimated regression coefficient for mean change, $0.021 \mathrm{mmol} / \mathrm{L}, 95 \% \mathrm{CI}-0.027$ to -0.015), HDL-cholesterol (estimated regression coefficient for mean change, $-0.032 \mathrm{mmol} /$ L, 95\% CI -0.042 to -0.022 ), LDL-cholesterol (estimated regression coefficient for mean change, $-0.019 \mathrm{mmol} / \mathrm{L}, 95 \% \mathrm{CI}$ -0.025 to -0.013 ) and triacylglycerol (estimated regression coefficient for mean change, $-0.026 \mathrm{mmol} / \mathrm{L}, 95 \% \mathrm{CI}-0.031$ to 0.020) (Mensink 2003). Nonetheless, Mensink 2003 included short term interventions and studies were not necessarily randomised. A meta-analysis of cohort studies which explicitly examined the effect of LA intake on CHD outcomes (myocardial infarction, ischemic heart disease, coronary artery bypass graft, sudden cardiac arrest, acute coronary syndrome, and CHD deaths) found a dose-response inverse association between dietary LA intake with CHD risk (Farvid 2014). However, observational studies are open to bias and confounding.

A recent meta-analysis of prospective, observational studies and RCTs examined the association between fatty acids and coronary disease. The meta-analysis of RCTs showed that omega- 6 intake did not significantly reduce the risk for coronary disease $0.86(95 \%$ CI 0.69 to 1.07$)$. It should be noted that the RCTs were eligible for this review only if they recorded coronary outcomes as an endpoint of interest (Chowdhury 2014) and were conducted predominantly in those with existing CVD, and so the focus of this review was secondary rather than primary prevention unlike the current review.

There have been previous systematic reviews of RCTs examining the effects of PUFA, including omega 6 intake but not explicitly focusing on this, on cardiovascular risk factors including lipid levels (Mozaffarian 2010; Hooper 2011) and CVD events (Mozaffarian 2010). These reviews used different inclusion criteria to the current review. Participants were included with or without existing CVD so the focus was not on primary prevention (Mozaffarian 2010; Hooper 2011). Additionally, it is difficult to disentangle the effect of omega 6 as this was not explicitly examined in each of the reviews (Mozaffarian 2010; Hooper 2011).

\section{AUTHORS' CONCLUSIONS}

\section{Implications for practice}

We have avoided making implications for practice as there is currently insufficient evidence for the effects of increased or decreased omega 6 intake on CVD events and CVD risk factors. 


\section{Implications for research}

Few trials met the inclusion criteria of this Cochrane review. All included trials were small, relatively short term, and at some risk of bias. None reported our primary outcomes. There is a need for large, well-designed, long term RCTs to assess the effect of increased or reduced omega 6 intake on cardiovascular events and risk factors to determine the effectiveness of either intervention for the primary prevention of CVD.

\section{ACKNOWLEDGEMENTS}

We are grateful to Nicole Martin for conducting the literature searches for this Cochrane review.

\section{RE F E R E N C E S}

\section{References to studies included in this review}

Moore 2006 High LA \{published data only\}

Moore CS, Bryant SP, Mishra GD, Krebs JD, Browning LM, Miller GJ, et al. Oily fish reduces plasma triaclyglycerols: a primary prevention study in overweight men and women. Nutrition 2006;22(10):1012-24.

Moore 2006 Low LA \{published data only\}

Moore CS, Bryant SP, Mishra GD, Krebs JD, Browning LM, Miller GJ, et al. Oily fish reduces plasma triaclyglycerols: a primary prevention study in overweight men and women. Nutrition 2006;22(10):1012-24.

OPTILIP 2006 \{published data only\}

Griffin MD, Sanders TA, Davies IG, Morgan LM, Millward DJ, Lewis $F$, et al. Effects of altering the ratio of dietary n-6 to n-3 fatty acids on insulin sensitivity, lipoprotein size, and postprandial lipemia in men and postmenopausal women aged 45-70 y: the OPTILIP Study. American Journal of Clinical Nutrition 2006;84(6):1290-8.

* Sanders TAB, Lewis F, Slaughter S, Griffin BA, Griffin M, Davies I, et al. Effect of varying the ratio of $n-6$ to $n-3$ fatty acids by increasing the dietary intake of alpha-linolenic acid, eicosapentaenoic and docosahexaenoic acid, or both on fibrinogen and clotting factors VII and XII in persons aged 45-70 y: the OPTILIP study. American Journal of Clinical Nutrition 2006;84(3):513-22.

Sarkkinen 1998 \{published data only\}

Sarkkinen ES, Uusitupa MI, Gylling H, Miettinen TA. Fatmodified diets influence serum concentrations of cholesterol precursors and plant sterols in hypercholesterolemic subjects. Metabolism 1998;47(6):744-50.

Sluijs 2010 \{published data only\}

Sluijs I, Plantinga Y, de Roos B, Mennen LI, Bots ML. Dietary supplementation with cis-9,trans-11 conjugated linoleic acid and aortic stiffness in overweight and obese adults. American Journal of Clinical Nutrition 2010;91(1): 175-83.

\section{References to studies excluded from this review}

Ahrén 2009 \{published data only\}

Ahrén B, Mari A, Fyfe CL, Tsofliou F, Sneddon AA, Wahle KW, et al. Effects of conjugated linoleic acid plus n-3 polyunsaturated fatty acids on insulin secretion and estimated insulin sensitivity in men. European Journal of Clinical Nutrition 2009;63(6):778-86.

Allman-Farinelli 1999 \{published data only\} Allman-Farinelli MA, Hall D, Kingham K, Pang D, Petocz P, Favaloro EJ. Comparison of the effects of two low fat diets with different alpha-linolenic:linoleic acid ratios on coagulation and fibrinolysis. Atherosclerosis 1999;142(1): 159-68.

Anderson 1957 \{published data only\}

Anderson JT, Grande F, Keys A. Essential fatty acids, degree of unsaturation, and effect of corn (maize) oil on the serumcholesterol level in man. Lancet 1957;272(6959):66-8.

Angela Liou 2009 \{published data only\}

Angela Liou Y, Innis SM. Dietary linoleic acid has no effect on arachidonic acid, but increases $\mathrm{n}-6$ eicosadienoic acid, and lowers dihomo--linolenic and eicosapentaenoic acid in plasma of adult men. Prostaglandins, Leukotrienes, and Essential Fatty Acids 2009;80(4):201-6.

Bachmair 2012 \{published data only\} Bachmair EM, Bots ML, Mennen LI, Kelder T, Evelo CT, Horgan GW, et al. Effect of supplementation with an 80:20 cis9,trans 11 conjugated linoleic acid blend on the human platelet proteome. Molecular Nutrition \& Food Research 2012;56(7):1148-59.

Becker 1983 \{published data only\} Becker N, Illingworth DR, Alaupovic P, Connor WE, Sundberg EE. Effects of saturated, monounsaturated, and 
omega-6 polyunsaturated fatty acids on plasma lipids, lipoproteins, and apoproteins in humans. American Journal of Clinical Nutrition 1983;37(3):355-60.

Belury 2009 \{published data only\} Belury M, Collene A, Norris L, Asp M, Hsu J, Li D, et al. Comparison of dietary oils on criteria of metabolic syndrome in postmenopausal women: a randomized crossover clinical intervention study. Journal of Diabetes 2009;1:A34.

Bemelmans 2000 \{published data only\} Bemelmans WJ, Muskiet FA, Feskens EJ, de Vries JH, Broer J, May JF, et al. Associations of alpha-linolenic acid and linoleic acid with risk factors for coronary heart disease. European Journal of Clinical Nutrition 2000;54(12):865-71.

Bemelmans 2004 \{published data only\} Bemelmans WJ, Lefrandt JD, Feskens EJ, van Haelst PL, Broer J, Meyboom-de Jong B, et al. Increased alphalinolenic acid intake lowers C-reactive protein, but has no effect on markers of atherosclerosis. European Journal of Clinical Nutrition 2004;58(7):1083-9.

Benito 2001 \{published data only\}

Benito P, Nelson GJ, Kelley DS, Bartolini G, Schmidt PC, Simon V. The effect of conjugated linoleic acid on plasma lipoproteins and tissue fatty acid composition in humans. [Erratum appears in Lipids 2001 Aug;36(8):857]. Lipids 2001;36(3):229-36.

Bermejo 2012 \{published data only\}

Bermejo LM, Rodriguez-Duran D, Lopez-Plaza B, ZuritaRosa L, Palma-Milla S, Weber TK, et al. Effects of a functional light cheese naturally enriched with CLA and omega-3 improving blood lipid profile in overweight and obese people treatment. Clinical Nutrition, Supplement 2012;7(1):219.

Bjermo 2012 \{published data only\} Bjermo H, Iggman D, Kullberg J, Dahlman I, Johansson L, Persson L, et al. Effects of n-6 PUFAs compared with SFAs on liver fat, lipoproteins, and inflammation in abdominal obesity: a randomized controlled trial. American Journal of Clinical Nutrition 2012;95(5):1003-12.

Blair 1993 \{published data only\}

Blair IA, Prakash C, Phillips MA, Dougherty RM, Iacono JM. Dietary modification of omega 6 fatty acid intake and its effect on urinary eicosanoid excretion. American Journal of Clinical Nutrition 1993;57(2):154-60.

Boberg 1986 \{published data only\}

Boberg M, Vessby B, Selinus I. Effects of dietary supplementation with $n-6$ and $n-3$ long-chain polyunsaturated fatty acids on serum lipoproteins and platelet function in hypertriglyceridaemic patients. Acta Medica Scandinavica 1986;220(2):153-60.

Bonanome 1992 \{published data only\} Bonanome A, Pagnan A, Biffanti S, Opportuno A, Sorgato F, Dorella M, et al. Effect of dietary monounsaturated and polyunsaturated fatty acids on the susceptibility of plasma low density lipoproteins to oxidative modification. Arteriosclerosis and Thrombosis 1992;12(4):529-33.
Bouwens 2009 \{published data only\}

Bouwens M, van De Rest O, Dellschaft N, Bromhaar MG, De Groot LC, Geleijnse JM, et al. Fish-oil supplementation induces antiinflammatory gene expression profiles in human blood mononuclear cells. American Journal of Clinical Nutrition 2009;90(2):415-24.

Brady 2004 \{published data only\}

Brady LM, Lovegrove SS, Lesauvage SV, Gower BA, Minihane AM, Williams CM, et al. Increased n-6 polyunsaturated fatty acids do not attenuate the effects of long-chain $\mathrm{n}-3$ polyunsaturated fatty acids on insulin sensitivity or triacylglycerol reduction in Indian Asians. American Journal of Clinical Nutrition 2004;79(6):983-91.

Bramkamp 1974 \{published data only\} Bramkamp K, Wirths W. Influence of linoleic acid enriched margarine on serum cholesterol levels in the elderly [Über den Einfluß von linolsäurereicher Margarine auf den Serumcholesterinspiegel älterer Menschen]. Zeitschrift für Ernährungswissenschaft 1974;13(1-2):59-68.

Bronsgeest-Schoute 1979 \{published data only\} Bronsgeest-Schoute DC, Hermus RJ, Dallinga-Thie GM, Hautvast JG. Dependence of the effects of dietary cholesterol and experimental conditions on serum lipids in man. II. Effects of dietary cholesterol in a linoleic acid-poor diet. American Journal of Clinical Nutrition 1979;32(11): 2188-92.

Brox 1981 \{published data only\} Brox JH, Killie JE, Gunnes S, Nordøy A. The effect of cod liver oil and corn oil on platelets and vessel wall in man. Thrombosis and Haemostasis 1981;46(3):604-11.

Burdge 2004 \{published data only\} Burdge GC, Lupoli B, Russell JJ, Tricon S, Kew S, Banerjee $\mathrm{T}$, et al. Incorporation of cis-9,trans-11 or trans-10,cis-12 conjugated linoleic acid into plasma and cellular lipids in healthy men. Journal of Lipid Research 2004;45(4):736-41.

\section{Camargo 2013 \{published data only\}}

Camargo A, Meneses M, Rangel-Zuniga, O, Pérez-Martínez P, Delgado-Lista J, Marín C, et al. Dietary fat modifies lipid metabolism in the adipose tissue of patients with metabolic syndrome. Annals of Nutrition and Metabolism 2013;62:63.

\section{Carvalho 2012 \{published data only\}}

Carvalho RF, Uehara SK, Rosa G. Microencapsulated conjugated linoleic acid associated with hypocaloric diet reduces body fat in sedentary women with metabolic syndrome. Vascular Health and Risk Management 2012;8: 661-7.

\section{Cater 1997 \{published data only\}} Cater NB, Heller HJ, Denke MA. Comparison of the effects of medium-chain triacylglycerols, palm oil, and high oleic acid sunflower oil on plasma triacylglycerol fatty acids and lipid and lipoprotein concentrations in humans. American Journal of Clinical Nutrition 1997;65(1):41-5.

Clandinin 1999 \{published data only\}

Clandinin MT, Cook SL, Konrad SD, Goh YK, French MA. The effect of palmitic acid on lipoprotein cholesterol levels 
and endogenous cholesterol synthesis in hyperlipidemic subjects. Lipids 1999;34 Suppl:S121-4.

Dayton 1962 \{published data only\}

Dayton S, Pearce ML, Hashimoto S, Fakler LJ, Hiscock E, Dixon WJ. A controlled clinical trial of a diet high in unsaturated fat. Preliminary observations. New England Journal of Medicine 1962;266:1017-23.

Deferne 1992 \{published data only\}

Deferne JL, Leeds AR. The antihypertensive effect of dietary supplementation with a 6-desaturated essential fatty acid concentrate as compared with sunflower seed oil. Journal of Human Hypertension 1992;6(2):113-9.

de Kok 2003 \{published data only\}

de Kok TM, Zwingman I, Moonen EJ, Schilderman PA, Rhijnsburger E, Haenen GR, et al. Analysis of oxidative DNA damage after human dietary supplementation with linoleic acid. Food and Chemical Toxicology 2003;41(3): $351-8$.

Dembinska-Kiec 2010 \{published data only\}

Dembinska-Kiec A, Malczewska-Malec M, Roche H, Leszczynska-Golabek I, Hartwich J, Wybranska I, et al. The effect of the n-3/n-6 PUFA ratio on the transformation of postprandial state proatherogenic LDL phenotype and oxidative stress parameters. Atherosclerosis Supplements. 2010; Vol. 11, issue 2:129-30.

Dembinska-Kiec 2011 \{published data only\} Dembinska-Kiec A, Malczewska-Malec M, Hartwich J, Wnek D, Goralska J, Kiec-Wilk B, et al. The effect of dietary intervention on proatherogenic profile of lipoproteins and the blood oxidative stress parameters measured in the course of postprandial lipemia: Lipgene study. Journal of Diabetes 2011;3(s1):28.

Elisha 2011 \{published data only\}

Elisha B, Guebre-Egziabher F, Vidal H, Bastard J, Laville M, Rabasa-Lhoret R. From French to Mediterranean Diet: importance of the omega-6/omega-3 fatty acids ratio. World Review of Nutrition and Dietetics 2011;102:81-91.

Failor 1988 \{published data only\}

Failor RA, Childs MT, Bierman EL. The effects of omega 3 and omega 6 fatty acid-enriched diets on plasma lipoproteins and apoproteins in familial combined hyperlipidemia. Metabolism: Clinical and Experimental 1988;37(11): $1021-8$.

Finnegan 2003a \{published data only\} Finnegan YE, Howarth D, Minihane AM, Kew S, Miller GJ, Calder PC, et al. Plant and marine derived (n-3) polyunsaturated fatty acids do not affect blood coagulation and fibrinolytic factors in moderately hyperlipidemic humans. Journal of Nutrition 2003;133(7):2210-3.

Finnegan 2003b \{published data only\} Finnegan YE, Minihane AM, Leigh-Firbank EC, Kew S, Meijer GW, Muggli R, et al. Plant- and marine-derived n3 polyunsaturated fatty acids have differential effects on fasting and postprandial blood lipid concentrations and on the susceptibility of LDL to oxidative modification in moderately hyperlipidemic subjects. American Journal of Clinical Nutrition 2003;77(4):783-95.

Friday 1991 \{published data only\}

Friday KE, Failor RA, Childs MT, Bierman EL. Effects of n-3 and n- 6 fatty acid-enriched diets on plasma lipoproteins and apolipoproteins in heterozygous familial hypercholesterolemia. Arteriosclerosis and Thrombosis 1991; 11(1):47-54.

Gaullier 2004 \{published data only\} Gaullier JM, Halse J, Høye K, Kristiansen K, Fagertun H, Vik H, et al. Conjugated linoleic acid supplementation for $1 \mathrm{y}$ reduces body fat mass in healthy overweight humans. American Journal of Clinical Nutrition 2004;79(6):1118-25.

Gaullier 2005 \{published data only\} Gaullier JM, Halse J, Høye K, Kristiansen K, Fagertun H, Vik H, et al. Supplementation with conjugated linoleic acid for 24 months is well tolerated by and reduces body fat mass in healthy, overweight humans. Journal of Nutrition 2005; 135(4):778-84.

Gaullier 2007 \{published data only\} Gaullier JM, Halse J, Høivik HO, Høye K, Syvertsen C, Nurminiemi M, et al. Six months supplementation with conjugated linoleic acid induces regional-specific fat mass decreases in overweight and obese. British Journal of Nutrition 2007;97(3):550-60.

Ghafoorunissa 1995 \{published data only\} Ghafoorunissa, Reddy V, Sesikaran B. Palmolein and groundnut oil have comparable effects on blood lipids and platelet aggregation in healthy Indian subjects. Lipids 1995; 30(12):1163-9.

Ghafoorunissa 2002 \{published data only\} Ghafoorunissa, Vani A, Laxmi R, Sesikeran B. Effects of dietary alpha-linolenic acid from blended oils on biochemical indices of coronary heart disease in Indians. Lipids 2002;37(11):1077-86.

Giacco 2007 \{published data only\} Giacco R, Cuomo V, Vessby B, Uusitupa M, Hermansen $\mathrm{K}$, Meyer BJ, et al. Fish oil, insulin sensitivity, insulin secretion and glucose tolerance in healthy people: is there any effect of fish oil supplementation in relation to the type of background diet and habitual dietary intake of n-6 and n-3 fatty acids?. Nutrition, Metabolism, and Cardiovascular Diseases: NMCD 2007;17(8):572-80.

Groen 1965 \{published data only\}

Groen JJ, Balogh M, Yaron E, Freeman J. Influence of the nature of the fat in diets high in carbohydrate (mainly derived from bread) on the serum cholesterol. American Journal of Clinical Nutrition 1965;17(5):296-304.

Grundt 1995 \{published data only\} Grundt H, Nilsen D, Hetland O, Aarsland T, Baksaas I, Grande T, et al. Improvement of serum lipids and blood pressure during intervention with $\mathrm{n}-3$ fatty acids was not associated with changes in insulin levels in subjects with combined hyperlipidaemia. Journal of Internal Medicine 1995;237:249-59. 


\section{Grønn 1991 \{published data only\}}

Grønn M, Gørbitz C, Christensen E, Levorsen A, Ose L, Hagve TA, et al. Dietary n-6 fatty acids inhibit the incorporation of dietary n-3 fatty acids in thrombocyte and serum phospholipids in humans: a controlled dietetic study. Scandinavian Journal of Clinical and Laboratory Investigation 1991;51(3):255-63.

Haglund 1998 \{published data only\} Haglund O, Wallin R, Wretling S, Hultberg B, Saldeen T. Effects of fish oil alone and combined with long chain (n-6) fatty acids on some coronary risk factors in male subjects. Journal of Nutritional Biochemistry 1998;9(11):629-35.

Harris 2009 \{published data only\}

Harris WS, Mozaffarian D, Rimm E, Kris-Etherton P, Rudel LL, Appel LJ, et al. Omega-6 fatty acids and risk for cardiovascular disease: a science advisory from the American Heart Association Nutrition Subcommittee of the Council on Nutrition, Physical Activity, and Metabolism; Council on Cardiovascular Nursing; and Council on Epidemiology and Prevention. Circulation 2009;119(6):902-7.

\section{Hartwich 2009 \{published data only\}}

Hartwich J, Malczewska-Malec M, Kiec-Wilk B, Leszczynska-Golabek I, Dembinska-Kiec A, Pérez-Martinez P, et al. The effect of the N-3/N-6 pufa ratio on the postprandial LDL phenotype and ischemia modified albumin (IMA). The LIPGENE study. Atherosclerosis Supplements. 2009; Vol. 10, issue 2.

Hartwich 2010 \{published data only\}

Hartwich J, Leszczynska-Golabek I, Kiec-Wilk B, Siedlecka D, Pérez-Martinez P, Marin C, et al. Lipoprotein profile, plasma ischemia modified albumin and LDL density change in the course of postprandial lipemia. Insights from the LIPGENE study. Scandinavian Journal of Clinical and Laboratory Investigation 2010;70(3):201-8.

Heine 1989 \{published data only\}

Heine RJ, Mulder C, Popp-Snijders C, van der Meer J, van der Veen EA. Linoleic-acid-enriched diet: long-term effects on serum lipoprotein and apolipoprotein concentrations and insulin sensitivity in noninsulin-dependent diabetic patients. American Journal of Clinical Nutrition 1989;49(3): $448-56$.

\section{Higdon 2000 \{published data only\}}

Higdon JV, Liu J, Du SH, Morrow JD, Ames BN, Wander RC. Supplementation of postmenopausal women with fish oil rich in eicosapentaenoic acid and docosahexaenoic acid is not associated with greater in vivo lipid peroxidation compared with oils rich in oleate and linoleate as assessed by plasma malondialdehyde and F(2)-isoprostanes. American Journal of Clinical Nutrition 2000;72(3):714-22.

Higdon 2001 \{published data only\}

Higdon JV, Du SH, Lee YS, Wu T, Wander RC. Supplementation of postmenopausal women with fish oil does not increase overall oxidation of LDL ex vivo compared to dietary oils rich in oleate and linoleate. Journal of Lipid Research 2001;42(3):407-18.

\section{Ho 1999 \{published data only\}}

Ho M, Maple C, Bancroft A, McLaren M, Belch JJ. The beneficial effects of omega- 3 and omega- 6 essential fatty acid supplementation on red blood cell rheology. Prostaglandins, Leukotrienes, and Essential Fatty Acids 1999;61(1):13-7.

\section{Hodson 2001 \{published data only\}}

Hodson L, Skeaff CM, Chisholm WA. The effect of replacing dietary saturated fat with polyunsaturated or monounsaturated fat on plasma lipids in free-living young adults. European Journal of Clinical Nutrition 2001;55(10): 908-15.

\section{Hui 1989 \{published data only\}}

Hui R, St-Louis J, Falardeau P. Anti-hypertensive properties of linoleic acid and fish oil omega-3 fatty acids independant of the prostaglandin system. American Journal of Hypertension 1989;2(8):610-7.

\section{Hwang 1997 \{published data only\}}

Hwang DH, Chanmugam PS, Ryan DH, Boudreau MD, Windhauser MM, Tulley RT, et al. Does vegetable oil attenuate the beneficial effects of fish oil in reducing risk factors for cardiovascular disease?. American Journal of Clinical Nutrition 1997;66(1):89-96.

Intorre 2013 \{published data only\} Intorre F, Venneria E, Finotti E, Foddai MS, Toti E, Catasta G, et al. Fatty acid content of serum lipid fractions and blood lipids in normolipidaemic volunteers fed two types of cheese having different fat compositions: a pilot study. International Journal of Food Sciences and Nutrition 2013;64 (2):185-93.

Iwata 2007 \{published data only\} Iwata T, Kamegai T, Yamauchi-Sato Y, Ogawa A, Kasai M, Aoyama T, et al. Safety of dietary conjugated linoleic acid (CLA) in a 12-weeks trial in healthy overweight Japanese male volunteers. Journal of Oleo Science 2007;56(10): 517-25.

Khan 2003 \{published data only\} Khan F, Elherik K, Bolton-Smith C, Barr R, Hill A, Murrie I, et al. The effects of dietary fatty acid supplementation on endothelial function and vascular tone in healthy subjects. Cardiovascular Research 2003;59(4):955-62.

\section{Kiecolt-Glaser 2013 \{published data only\}} Kiecolt-Glaser JK, Epel ES, Belury MA, Andridge R, Lin J, Glaser R, et al. Omega-3 fatty acids, oxidative stress, and leukocyte telomere length: A randomized controlled trial. Brain, Behavior, and Immunity 2013;28:16-24.

\section{Kim 2009 \{published data only\}}

Kim JH, Kim OH, Jung H. Effects of supplementation of conjugated linoleic acid with gammaoryzanol on body fat mass in healthy overweight Korean women. FASEB Journal. 2009; Vol. 23 (Meeting Abstract Supplement), issue 1:563.26.

\section{Kingsbury 1961 \{published data only\}} Kingsbury KJ, Aylott C, Morgan DM, Emmerson R. Effects of ethyl arachidonate, cod-liver oil, and corn oil on the plasma-cholesterol level. A comparison in normal volunteers. Lancet 1961;1(7180):739-41. 
Knapp 1989 \{published data only\}

Knapp HR, FitzGerald GA. The antihypertensive effects of fish oil. A controlled study of polyunsaturated fatty acid supplements in essential hypertension. New England Journal of Medicine 1989;320(16):1037-43.

Koyama 2009 \{published data only\}

Koyama N, Suzuki K, Furukawa Y, Arisaka H, Seki T, Kuribayashi K, et al. Effects of safflower seed extract supplementation on oxidation and cardiovascular risk markers in healthy human volunteers. British Journal of Nutrition 2009;101(4):568-75.

Lambert 2007 \{published data only\}

Lambert EV, Goedecke JH, Bluett K, Heggie K, Claassen A, Rae DE, et al. Conjugated linoleic acid versus high-oleic acid sunflower oil: effects on energy metabolism, glucose tolerance, blood lipids, appetite and body composition in regularly exercising individuals. British Journal of Nutrition 2007;97(5):1001-11.

Lands 1992 \{published data only\}

Lands WE, Libelt B, Morris A, Kramer NC, Prewitt TE, Bowen P, et al. Maintenance of lower proportions of (n-6) eicosanoid precursors in phospholipids of human plasma in response to added dietary (n-3) fatty acids. Biochimica et Biophysica Acta 1992;1180(2):147-62.

Lee 2012 \{published data only\}

Lee SP, Dart AM, Walker KZ, O'Dea K, Chin-Dusting JP Skilton MR. Effect of altering dietary n-6:n-3 PUFA ratio on cardiovascular risk measures in patients treated with statins: a pilot study. British Journal of Nutrition 2012;108 (7):1280-5.

Legrand 2010 \{published data only\}

Legrand P, Schmitt B, Mourot J, Catheline D, Chesneau G, Mireaux M, et al. The consumption of food products from linseed-fed animals maintains erythrocyte omega-3 fatty acids in obese humans. Lipids 2010;45(1):11-9.

MARGARIN 2002 \{published data only\}

* Bemelmans WJ, Broer J, Feskens EJ, Smit AJ, Muskiet FA, Lefrandt JD, et al. Effect of an increased intake of $\alpha$-linolenic acid and group nutritional education on cardiovascular risk factors: the Mediterranean Alphalinolenic Enriched Groningen Dietary Intervention (MARGARIN) study. American Journal of Clinical Nutrition 2002;75(2):221-7.

Bemelmans WJ, Broer J, de Vries JH, Hulshof KF, May JF, Meyboom-de Jong B. Impact of Mediterramean diet education versus posted leaflet on dietary habits and serum cholesterol in a high risk population for cardiovascular disease. Public Health Nutrition 2000;3(3):273-83.

Margolin 1990 \{published data only\}

Margolin G, Huster G, Glueck CJ, Speirs J, Vandegrift J, Illig E. Blood-pressure lowering in the elderly - a doubleblind crossover study of omega- 3 and omega- 6 fatty-acids. American Journal of Clinical Nutrition 1990;51(3):518.

Margolin 1991 \{published data only\}

Margolin G, Huster G, Glueck CJ, Speirs J, Vandegrift J, Illig E, et al. Blood pressure lowering in elderly subjects: a double-blind crossover study of omega- 3 and omega- 6 fatty acids. American Journal of Clinical Nutrition 1991;53(2): 562-72.

\section{McDaniel 2010 \{published data only\}}

McDaniel JC, Ahijevych K, Belury M. Effect of n-3 oral supplements on the $\mathrm{n}-6 / \mathrm{n}-3$ ratio in young adults. Western Journal of Nursing Research 2010;32(1):64-80.

Mendis 2001 \{published data only\}

Mendis S, Samarajeewa U, Thattil RO. Coconut fat and serum lipoproteins: effects of partial replacement with unsaturated fats. British Journal of Nutrition 2001;85(5): 583-9.

Miles 2004 \{published data only\}

Miles EA, Banerjee T, Calder PC. The influence of different combinations of gamma-linolenic, stearidonic and eicosapentaenoic acids on the fatty acid composition of blood lipids and mononuclear cells in human volunteers. Prostaglandins, Leukotrienes, and Essential Fatty Acids 2004; 70(6):529-38.

\section{Mills 1989 \{published data only\}}

Mills DE, Prkachin KM, Harvey KA, Ward RP. Dietary fatty acid supplementation alters stress reactivity and performance in man. Journal of Human Hypertension 1989; 3(2):111-6.

Minihane 2005 \{published data only\} Minihane AM, Brady LM, Lovegrove SS, Lesauvage SV, Williams CM, Lovegrove JA. Lack of effect of dietary n-6: n-3 PUFA ratio on plasma lipids and markers of insulin responses in Indian Asians living in the UK. European Journal of Nutrition 2005;44(1):26-32.

Misikangas 2001 \{published data only\} Misikangas M, Freese R, Turpeinen AM, Mutanen M. High linoleic acid, low vegetable, and high oleic acid, high vegetable diets affect platelet activation similarly in healthy women and men. Journal of Nutrition 2001;131(6):1700-5.

\section{Mortensen 1983 \{published data only\}}

Mortensen JZ, Schmidt EB, Nielsen AH, Dyerberg J. The effect of N-6 and N-3 polyunsaturated fatty acids on hemostasis, blood lipids and blood pressure. Thrombosis and Haemostasis 1983;50(2):543-6.

Møller 1992 \{published data only\} Møller J, Svaneborg N, Lervang HH, Varming K, Madsen $\mathrm{P}$, Dyerberg J, et al. The acute effect of a single very high dose of N-3 fatty acids on coagulation and fibrinolysis. Thrombosis Research 1992;67(5):569-77.

Naber 1992 \{published data only\} Naber FB, Oudkerk Pool M, Teerlink T, Popp-Snijders C, Gans RO, Bilo HJ. Effect of short-term use of omega3-type polyunsaturated fatty acids in subjects with hypertriglyceridemia [Dutch]. Nederlands Tijdschrift voor Geneeskunde 1992;136(31):1511-4.

Naumann 2006 \{published data only\} Naumann E, Carpentier YA, Saebo A, Lassel TS, Chardigny JM, Sébédio JM, et al. Cis-9, trans- 11 and trans-10, cis12 conjugated linoleic acid (CLA) do not affect the plasma 
lipoprotein profile in moderately overweight subjects with LDL phenotype B. Atherosclerosis 2006;188(1):167-74.

\section{Nelson 1997a \{published data only\}}

Nelson GJ, Schmidt PC, Bartolini G, Kelley DS, Phinney SD, Kyle D, et al. The effect of dietary arachidonic acid on plasma lipoprotein distributions, apoproteins, blood lipid levels, and tissue fatty acid composition in humans. Lipids 1997;32(4):427-33.

Nelson 1997b \{published data only\}

Nelson GJ, Kelley DS, Emken EA, Phinney SD, Kyle D, Ferretti A. A human dietary arachidonic acid supplementation study conducted in a metabolic research unit: rationale and design. Lipids 1997;32(4):415-20.

Nestel 1992 \{published data only\}

Nestel P, Noakes M, Belling GB, McArthur R, Clifton RM, Abbey M. Plasma cholesterol-lowering potential of edibleoil blends suitable for commercial use. American Journal of Clinical Nutrition 1992;55(1):46-50.

Nestel 1995 \{published data only\} Nestel PJ, Noakes M, Belling GB, McArthur R, Clifton PM. Effect on plasma lipids of interesterifying a mix of edible oils. American Journal of Clinical Nutrition 1995;62 (5):950-5.

Noakes 1996 \{published data only\} Noakes M, Nestel P, Clifton P. Commercial frying fats and plasma lipid-lowering potential. Australian Journal of Nutrition and Dietetics 1996;53(1):25-30.

Oe 2008 \{published data only\}

Oe H, Hozumi T, Murata E, Matsuura H, Negishi K, Matsumura Y, et al. Arachidonic acid and docosahexaenoic acid supplementation increases coronary flow velocity reserve in Japanese elderly individuals. Heart 2008;94(3): $316-21$.

\section{Paschos 2007 \{published data only\}}

Paschos GK, Zampelas A, Panagiotakos DB, Katsiougiannis S, Griffin BA, Votteas V, et al. Effects of flaxseed oil supplementation on plasma adiponectin levels in dyslipidemic men. European Journal of Nutrition 2007;46 (6):315-20.

\section{Pał kowska 2012 \{published data only\}}

Pat kowska E, Bartnikowska E, Owsiak D. The use of lowcaloric diet with modified fatty acids pool in the therapy of

the metabolic syndrome. Roczniki Pań stwowego Zakł adu Higieny 2012;63(2):163-9.

Perez-Martinez 2010 \{published data only\} Perez-Martinez P, Garcia-Quintana J, Yubero-Serrano E, Tasset-Cuevas I, Tunez I, Garcia-Rios A, et al. Postprandial oxidative stress is modified by dietary fat: evidence from a human intervention study. Clinical Science 2010;119(6): 251-61.

Perkins 1958 \{published data only\} Perkins R, Wright IS, Gatje BW. Effect of safflower oil emulsion on serum cholesterol levels in young adult males.
Its use as a supplement to a normal diet. Journal of the American Medical Association 1958;166(17):2132-5.

Radack 1990 \{published data only\}

Radack K, Deck C, Huster G. The comparative effects of $\mathrm{n}$ 3 and $n-6$ polyunsaturated fatty acids on plasma fibrinogen levels: a controlled clinical trial in hypertriglyceridemic subjects. Journal of the American College of Nutrition 1990;9 (4):352-7.

Radack 1991 \{published data only\} Radack K, Deck C, Huster G. The effects of low doses of $\mathrm{n}-3$ fatty acid supplementation on blood pressure in hypertensive subjects. A randomized controlled trial. Archives of Internal Medicine 1991;151(6):1173-80.

Rajaram 2012 \{published data only\}

Rajaram S, Sabate J, Mohan S. Effect of n-3 polyunsaturated fatty acids on peroxisome proliferator-activated receptor gamma (PPAR $\gamma)$ expression in adults. FASEB Journal. 2012; Vol. 26:823.28.

Rallidis 2003 \{published data only\} Rallidis LS, Paschos G, Liakos GK, Velissaridou AH, Anastasiadis G, Zampelas A. Dietary alpha-linolenic acid decreases $C$-reactive protein, serum amyloid $A$ and interleukin-6 in dyslipidaemic patients. Atherosclerosis 2003; 167(2):237-42.

Rallidis 2004 \{published data only\} Rallidis LS, Paschos G, Papaioannou M, Liakos GK, Panagiotakos DB, Anastasiadis G, et al. The effect of diet enriched with alpha-linolenic acid on soluble cellular adhesion molecules in dyslipidaemic patients. Atherosclerosis 2004;174(1):127-32.

Ramprasath 2012 \{published data only\} Ramprasath VR, Jones PJ, Buckley DD, Woollett LA, Heubi JE. Decreased plasma cholesterol concentrations after PUFA-rich diets are not due to reduced cholesterol absorption/synthesis. Lipids 2012;47(11):1063-71.

\section{Reaven 1991 \{published data only\}}

Reaven P, Parthasarathy S, Grasse BJ, Miller E, Almazan F, Mattson FH, et al. Feasibility of using an oleate-rich diet to reduce the susceptibility of low-density lipoprotein to oxidative modification in humans. American Journal of Clinical Nutrition 1991;54(4):701-6.

Risérus 2002a \{published data only\} Risérus U, Basu S, Jovinge S, Fredrikson G, Arnlöv J, Vessby B. Supplementation with conjugated linoleic acid causes isomer-dependent oxidative stress and elevated Creactive protein: a potential link to fatty acid-induced insulin resistance. Circulation 2002;106(15):1925-9.

Risérus 2002b \{published data only\} Risérus U, Arner P, Brismar K, Vessby B. Treatment with dietary trans10cis 12 conjugated linoleic acid causes isomerspecific insulin resistance in obese men with the metabolic syndrome. Diabetes Care 2002;25(9):1516-21.

Risérus 2004 \{published data only\} Risérus U, Vessby B, Arner P, Zethelius B. Supplementation with trans10cis12-conjugated linoleic acid induces 
hyperproinsulinaemia in obese men: close association with impaired insulin sensitivity. Diabetologia 2004;47(6): 1016-9.

Robertson 2002 \{published data only\} Robertson MD, Jackson KG, Fielding BA, Morgan LM, Williams CM, Frayn KN. Acute ingestion of a meal rich in $\mathrm{n}-3$ polyunsaturated fatty acids results in rapid gastric emptying in humans. American Journal of Clinical Nutrition 2002;76(1):232-8.

Roche 2009 \{published data only\}

Roche H, Ferguson JF, Perez-Martinez P, Lovegrove JA, Drevon CA, Defoort C, et al. Dietary fats, inflammation and insulin resistance-insights from the lipgene study. Atherosclerosis Supplements 2009;10:2.

Sanders 1983 \{published data only\} Sanders TA, Hochland MC. A comparison of the influence on plasma lipids and platelet function of supplements of omega 3 and omega 6 polyunsaturated fatty acids. British Journal of Nutrition 1983;50(3):521-9.

Sanders 1997 \{published data only\} Sanders TA, Oakley FR, Miller GJ, Mitropoulos KA, Crook $\mathrm{D}$, Oliver MF. Influence of $\mathrm{n}-6$ versus $\mathrm{n}-3$ polyunsaturated fatty acids in diets low in saturated fatty acids on plasma lipoproteins and hemostatic factors. Arteriosclerosis, Thrombosis, and Vascular Biology 1997;17(12):3449-60.

Singer 1991 \{published data only\}

Singer P, Wirth M, Kretschmer H. Different changes of n-6 fatty acids in lipoproteins from hyperlipemic subjects after diets supplemented with n-3 fatty acids. Prostaglandins, Leukotrienes, and Essential Fatty Acids 1991;42(2):107-11.

Sirtori 1992 \{published data only\}

Sirtori CR, Gatti E, Tremoli E, Galli C, Gianfranceschi G, Franceschini G, et al. Olive oil, corn oil, and n-3 fatty acids differently affect lipids, lipoproteins, platelets, and superoxide formation in type II hypercholesterolemia. American Journal of Clinical Nutrition 1992;56(1):113-22.

Smedman 2001 \{published data only\}

Smedman A, Vessby B. Conjugated linoleic acid supplementation in humans--metabolic effects. Lipids 2001;36(8):773-81.

Sofi 2010 \{published data only\}

Sofi F, Buccioni A, Cesari F, Gori A, Minieri S, Mannini L, et al. Effects of a dairy product (pecorino cheese) naturally rich in cis- 9 , trans- 11 conjugated linoleic acid on lipid, inflammatory and haemorheological variables: a dietary intervention study. Nutrition, Metabolism, and Cardiovascular Diseases 2010;20(2):117-24.

Sofi 2013 \{published data only\}

Sofi F, Giorgi G, Cesari G, Gori AM, Mannini L, Parisi G, et al. The atherosclerotic risk profile is affected differently by fish flesh with a similar EPA and DHA content but different n-6/n-3 ratio. Asia Pacific Journal of Clinical Nutrition 2013;22(1):32-40.

Solà 1997 \{published data only\}

Solà R, La Ville AE, Richard JL, Motta C, Bargalló MT, Girona J, et al. Oleic acid rich diet protects against the oxidative modification of high density lipoprotein. Free Radical Biology \& Medicine 1997;22(6):1037-45.

Song 2005 \{published data only\}

Song HJ, Grant I, Rotondo D, Mohede I, Sattar N, Heys $\mathrm{SD}$, et al. Effect of CLA supplementation on immune function in young healthy volunteers. European Journal of Clinical Nutrition 2005;59(4):508-17.

Steck 2007 \{published data only\} Steck SE, Chalecki AM, Miller P, Conway J, Austin GL, Hardin JW, et al. Conjugated linoleic acid supplementation for twelve weeks increases lean body mass in obese humans. Journal of Nutrition 2007;137(5):1188-93.

\section{Sundram 1992 \{published data only\}}

Sundram K, Hornstra G, von Houwelingen AC, Kester AD. Replacement of dietary fat with palm oil: effect on human serum lipids, lipoproteins and apolipoproteins. British Journal of Nutrition 1992;68(3):677-92.

Svaneborg 1994 \{published data only\} Svaneborg N, Møller JM, Schmidt EB, Varming K, Lervang $\mathrm{HH}$, Dyerberg J. The acute effects of a single very high dose of n-3 fatty acids on plasma lipids and lipoproteins in healthy subjects. Lipids 1994;29(2):145-7.

Tavakkoli 2010 \{published data only\}

Tavakkoli D, Hosseinpanah F, Tahbaz F, Amiri Z, Tavakkoli D, Hedayati M. Effects of conjugated linoleic acid supplementation on body composition and leptin concentration in post-menopausal women [Arabic]. Iranian Journal of Endocrinology and Metabolism 2010;12(1):48-59, 84.

Taylor 2006 \{published data only\} Taylor JS, Williams SR, Rhys R, James P, Frenneaux MP. Conjugated linoleic acid impairs endothelial function. Arteriosclerosis, Thrombosis, and Vascular Biology 2006;26 (2):307-12.

Tholstrup 2008 \{published data only\} Tholstrup T, Raff M, Straarup EM, Lund P, Basu S, Bruun JM. An oil mixture with trans-10, cis-12 conjugated linoleic acid increases markers of inflammation and in vivo lipid peroxidation compared with cis-9, trans-11 conjugated linoleic acid in postmenopausal women. Journal of Nutrition 2008;138(8):1445-51.

Tierney 2011 \{published data only\} Tierney AC, McMonagle J, Shaw DI, Gulseth HL, Helal $\mathrm{O}$, Saris $\mathrm{WH}$, et al. Effects of dietary fat modification on insulin sensitivity and on other risk factors of the metabolic syndrome--LIPGENE: a European randomized dietary intervention study. International Journal of Obesity 2011;35 (6):800-9.

\section{Truswell 2000 \{published data only\}}

Truswell AS. Comparing palmolein with different predominantly monounsaturated oils: effect on plasma lipids. International Journal of Food Sciences and Nutrition 2000;15 Suppl:S73-7.

\section{Tsai 1997 \{published data only\}}

Tsai PJ, Lu SC. Fish oil lowers plasma lipid concentrations and increases the susceptibility of low density lipoprotein 
to oxidative modification in healthy men. Journal of the Formosan Medical Association 1997;96(9):718-26.

Tsofliou 2009 \{published data only\}

Tsofliou F, Fyfe C, Matheson I, Jackson D, Horgan G, Wahle K, et al. Fasted and postprandial plasma lipids in healthy volunteers by a dietary mixture of omega-3 fatty acid modulation and conjugated linoleic acid. Journal of Food Lipids 2009;16:499-513.

Tulk 2009 \{published data only\}

Tulk HM, Robinson LE. Modifying the n-6/n-3 polyunsaturated fatty acid ratio of a high-saturated fat challenge does not acutely attenuate postprandial changes in inflammatory markers in men with metabolic syndrome. Metabolism: Clinical and Experimental 2009;58(12): 1709-16.

\section{Valsta 1996 \{published data only\}}

Valsta LM, Salminen I, Aro A, Mutanen M. Alpha-linolenic acid in rapeseed oil partly compensates for the effect of fish restriction on plasma long chain n-3 fatty acids. European Journal of Clinical Nutrition 1996;50(4):229-35.

Venter 1988 \{published data only\}

Venter CP, Joubert PH, Booyens J. Effects of essential fatty acids on mild to moderate essential hypertension. Prostaglandins, Leukotrienes, and Essential Fatty Acids 1988; 33(1):49-51.

Vergroesen 1980 \{published data only\}

Vergroesen AJ, de Deckere EA, ten Hoor F, Hornstra G. Cardiovascular effects of linoleic acid. Progress in Food \& Nutrition Science 1980;4(5):13-25.

Vericel 1987 \{published data only\}

Vericel E, Lagarde M, Mendy F. Comparative effects of linoleic acid and gamma-linolenic acid intake on plasma lipids and platelet phospholipids in elderly people. Nutrition Research 1987;7:569-80.

Vermunt 2001 \{published data only\}

Vermunt SH, Beaufrère B, Riemersma RA, Sébédio JL, Chardigny JM, Mensink RP, et al. Dietary trans alphalinolenic acid from deodorised rapeseed oil and plasma lipids and lipoproteins in healthy men: the TransLinE Study. British Journal of Nutrition 2001;85(3):387-92.

Viikari 1986 \{published data only\}

Viikari J, Lehtonen A. Effect of primrose oil on serum lipids and blood pressure in hyperlipidemic subjects. International Journal of Clinical Pharmacology, Therapy, and Toxicology 1986;24(12):668-70.

West 2010 \{published data only\}

West SG, Krick AL, Klein LC, Zhao G, Wojtowicz TF, McGuiness M, et al. Effects of diets high in walnuts and flax oil on hemodynamic responses to stress and vascular endothelial function. Journal of the American College of Nutrition 2010;29(6):595-603.

Wilkinson 2005 \{published data only\} Wilkinson P, Leach C, Ah-Sing EE, Hussain N, Miller GJ, Millward DJ, et al. Influence of alpha-linolenic acid and fish-oil on markers of cardiovascular risk in subjects with an atherogenic lipoprotein phenotype. Atherosclerosis 2005; 181(1):115-24.

Yam 2001 \{published data only\}

Yam D, Bott-Kanner G, Genin I, Shinitzky M, Klainman E. The effect of omega-3 fatty acids on risk factors for cardiovascular diseases [Hebrew]. Harefuah 2001;140(12): 1156-8, 1230.

Zhao 2004 \{published data only\} Zhao G, Etherton TD, Martin KR, West SG, Gillies PJ, Kris-Etherton PM. Dietary a-linolenic acid reduces inflammatory and lipid cardiovascular risk factors in hypercholesterolemic men and women. Journal of Nutrition 2004;134(11):2991-7.

Zhao 2007 \{published data only\}

Zhao G, Etherton TD, Martin KR, Gillies PJ, West SG, Kris-Etherton PM. Dietary alpha-linolenic acid inhibits proinflammatory cytokine production by peripheral blood mononuclear cells in hypercholesterolemic subjects. American Journal of Clinical Nutrition 2007;85(2):385-91.

\section{References to studies awaiting assessment}

\section{Natvig 1967 High LA \{published data only\}}

Natvig $H$. The effect of unsaturated fatty acids on the incidence of coronary infarction [Effekten av umettede fettsyrer pa hyppigheten av hjerteinfarkt m.m. Resultatet av bedrifslegenes 'oljeforsok']. Tidsskrift for den Norske lageforening 1967;87(11):1033-41.

Natvig 1967 Low LA \{published data only\} Natvig H. The effect of unsaturated fatty acids on the incidence of coronary infarction [Effekten av umettede fettsyrer pa hyppigheten av hjerteinfarkt m.m. Resultatet av bedrifslegenes 'oljeforsok']. Tidsskrift for den Norske lageforening 1967;87(11):1033-41.

Nordoy 1981 \{published data only\} Nordoy A, Brox JH, Killie JE. Influence of cod liver oil and corn oil on platelets and vessel wall in man [abstract]. Thrombosis and Haemostasis 1981;46(1):178.

Ryu 1999 \{published data only\}

Ryu S, Fisher J, Snook J. Polyunsaturated fatty acid (PUFA) intake in the development of heart disease in participants in the lipid research clinics coronary primary prevention trial (LRC-CPPT). FASEB Journal 1999;13:A933.

Singer 1993 \{published data only\}

Singer P. Different changes of N-6 fatty acids in lipoproteins from hyperlipaemic subjects after diets supplemented with N-3 fatty acids [German]. Aktuelle Ernährungsmedizin Klinik und Praxis 1993;18:368-72.

\section{Additional references}

Begg 2007

Begg S, Vos T, Barker B, Stevenson C, Stanley L, Lopez A. The burden of disease and injury in Australia 2003. www.aihw.gov.au/publication-detail/?id=6442467990 (accessed 24 April 2014). 


\section{BHF 2013}

British Heart Foundation. Cardiovascular disease. www.bhf.org.uk/heart-health/conditions/cardiovasculardisease.aspx (accessed 24 April 2014).

\section{Calder 2013}

Calder PC. Omega-3 polyunsaturated fatty acids and inflammatory processes: nutrition or pharmacology?. British Journal of Clinical Pharmacology 2013;75(3):645-62.

\section{Chowdhury 2014}

Chowdhury R, Warnakula S, Kunutsor S, Crowe F, Ward HA, Johnson L, et al. Association of dietary, circulating, and supplement fatty acids with coronary risk: a systematic review and meta-analysis. Annals of Internal Medicine 2014; 160(6):398-406.

\section{Esrey 1996}

Esrey KL, Joseph L, Grover SA. Relationship between dietary intake and coronary heart disease mortality: lipid research clinics prevalence follow-up study. Journal of Clinical Epidemiology 1996;49(2):211-6.

\section{Farvid 2014}

Farvid MS, Ding M, Pan A, Sun Q, Chiuve SE, Steffen LM, et al. Dietary linoleic acid and risk of coronary heart disease: a systematic review and meta-analysis of prospective cohort studies. Circulation 2014;130(18):1568-78.

\section{Follman 1992}

Follmann D, Elliott P, Suh I, Cutler J. Variance imputation for overviews of clinical trials with continuous response. Journal of Clinical Epidemiology 1992;45(7):769-73.

\section{Gaziano 2010}

Gaziano TA, Bitton A, Anand S, Abrahams-Gessel S, Murphy A. Growing epidemic of coronary heart disease in low- and middle-income countries. Current Problems in Cardiology 2010;35(2):72-115.

\section{Groff 1995}

Groff JL, Gropper SS, Hunt SM. Advanced Nutrition and Human Metabolism. 2nd Edition. New York: Wandsworth Publishing, 1995.

\section{Hall 2009}

Hall WL. Dietary saturated and unsaturated fats as determinants of blood pressure and vascular function. Nutrition Research Reviews 2009;22(1):18-38.

\section{Harris 2007}

Harris WS, Poston WC, Haddock CK. Tissue n-3 and n6 fatty acids and risk for coronary heart disease events. Atherosclerosis 2007;193(1):1-10.

\section{Harris 2010}

Harris W. Omega-6 and omega-3 fatty acids: partners in prevention. Current Opinion in Clinical Nutrition and Metabolic Care 2010;13(2):125-9.

\section{Hartley 2014}

Hartley L, Clar C, Flowers N, Hooper L, Rees K. Omega 6 fatty acids for the primary prevention of cardiovascular disease. Cochrane Database of Systematic Reviews 2014, Issue 5. [DOI: 10.1002/14651858.CD011094]
He 2003

He K, Merchant A, Rimm EB, Rosner BA, Stampfer MJ, Willett WC, et al. Dietary fat intake and risk of stroke in male US healthcare professionals: 14 year prospective cohort study. BMJ 2003;327(7418):777-82.

He 2010

He FJ, MacGregor GA. Reducing population salt intake worldwide: from evidence to implementation. Progress in Cardiovascular Diseases 2010;52(5):363-82.

\section{Higgins 2011}

Higgins JPT, Green S (editors). Cochrane Handbook for Systematic Reviews of Interventions Version 5.1.0 [updated March 2011]. The Cochrane Collaboration, 2011. Available from www.cochrane-handbook.org.

\section{Hooper 2011}

Hooper L, Summerbell CD, Thompson R, Sills D, Roberts FG, Moore H, et al. Reduced or modified dietary fat for preventing cardiovascular disease. Cochrane Database of Systematic Reviews 2011, Issue 7. [DOI: 10.1002/ 14651858.CD002137.pub2]

\section{Jakobsen 2009}

Jakobsen MU, O'Reilly EJ, Heitmann BL, Pereira MA, Bälter K, Fraser GE, et al. Major types of dietary fat and risk of coronary heart disease: a pooled analysis of 11 cohort studies. American Journal of Clinical Nutrition 2009;89(5): 1425-32.

\section{Katan 2009}

Katan MB. Omega-6 polyunsaturated fatty acids and coronary heart disease. American Journal of Clinical Nutrition 2009;89(5):1283-4.

\section{Laaksonen 2005}

Laaksonen DE, Nyyssönen K, Niskanen L, Rissanen TH, Salonen JT. Prediction of cardiovascular mortality in middle-aged men by dietary and serum linoleic and polyunsaturated fatty acids. Archives of Internal Medicine 2005;165(2):193-9.

Law 1999

Law M, Wald N. Why heart disease mortality is low in France: the time lag explanation. BMJ 1999;318(7196): 1471-6.

Lefebvre 2011

Lefebvre C, Manheimer E, Glanville J. Chapter 6: Searching for studies. In: Higgins JPT, Green S (editors). Cochrane Handbook for Systematic Reviews of Interventions. Version 5.1.0 [updated March 2011]. The Cochrane Collaboration, 2011. Available from www.cochrane-handbook.org.

\section{McGee 1984}

McGee DL, Reed DM, Yano K, Kagan A, Tillotson J. Tenyear incidence of coronary heart disease in the Honolulu Heart Program: relationship to nutrient intake. American Journal of Epidemiology 1984;119(5):667-76.

\section{Mensink 2003}

Mensink RP, Zock PL, Kester AD, Katan MB. Effects of dietary fatty acids and carbohydrates on the ratio of serum total to HDL cholesterol and on serum lipids and 
apolipoproteins: a meta-analysis of 60 controlled trials. American Journal of Clinical Nutrition 2003;77(5):1146-55.

\section{Mozaffarian 2010}

Mozaffarian D, Micha R, Wallace S. Effects on coronary heart disease of increasing polyunsaturated fat in place of saturated fat: a systematic review and meta-analysis of randomized controlled trials. PLoS Medicine 2010;7(3): e1000252.

\section{Müller-Nordhorn 2008}

Müller-Nordhorn J, Binting S, Roll S, Willich SN. An update on regional variation in cardiovascular mortality within Europe. European Heart Journal 2008;29(10): 1316-26.

\section{NHS 2012}

National Health Service. Atherosclerosis, 2012. www.nhs.uk/conditions/Atherosclerosis/Pages/ Introduction.aspx\#commentCountLink (accessed 24 April 2014).

Oh 2005

Oh K, Hu FB, Manson JE, Stampfer MJ, Willett WC. Dietary fat intake and risk of coronary heart disease in women: 20 years of follow-up of the nurses' health study. American Journal of Epidemiology 2005;161(7):672-9.

\section{Pietinen 1997}

Pietinen P, Ascherio P, Korhonen P, Hartman A, Willett WC, Albanes D, et al. Intake of fatty acids and risk of coronary heart disease in a cohort of Finnish men. The Alpha-Tocopherol, Beta-Carotene Cancer Prevention Study. American Journal of Epidemiology 1997;145(10):876-87.

\section{Ramsden 2013}

Ramsden CE, Zamora D, Leelarthaepin B, MajchrzakHong SF, Faurot KR, Suchindran CM, et al. Use of dietary linoleic acid for secondary prevention of coronary heart disease and death: evaluation of recovered data from the
Sydney Diet Heart Study and updated meta-analysis. BMJ 2013;346:e8707.

\section{RevMan 2014}

The Nordic Cochrane Centre, The Cochrane Collaboration. Review Manager (RevMan). 5.3. Copenhagen: The Nordic Cochrane Centre, The Cochrane Collaboration, 2014.

\section{Rincón-Cervera 2009}

Rincón-Cervera M, Rodríguez-García I, Guil-Guerrero J. Purification of GLA-triglycerides from evening primrose oil by gravimetric column chromatography. Journal of the American Oil Chemists' Society 2009;86(7):605-9.

\section{Russo 2009}

Russo GL. Dietary n-6 and n-3 polyunsaturated fatty acids: from biochemistry to clinical implications in cardiovascular prevention. Biochemical Pharmacology 2009;77(6):937-46.

Siri-Tarino 2010

Siri-Tarino PW, Sun Q, Hu FB, Krauss RM. Meta-analysis of prospective cohort studies evaluating the association of saturated fat with cardiovascular disease. American Journal of Clinical Nutrition 2010;91(3):535-46.

\section{Spagnoli 2007}

Spagnoli L, Bonanno E, Sangiorgi G, Mauriello A. Role

of infl ammation in atherosclerosis. Journal of Nuclear Medicine 2007;48(11):1800-15.

\section{Whelan 2011}

Rett BS, Whelan J. Increasing dietary linoleic acid does not increase tissue arachidonic acid content in adults consuming Western-type diets: a systematic review. Nutrition \& Metabolism 2011;8:36.

\section{WHO 2014}

World Health Organization. Cardiovascular diseases (CVDs). Fact sheet number 317. www.who.int/ mediacentre/factsheets/fs317/en/ (accessed 24 April 2014).

* Indicates the major publication for the study 


\section{CHARACTERISTICS OF STUDIES}

\section{Characteristics of included studies [ordered by study ID]}

\section{Moore 2006 High LA}

\begin{tabular}{|c|c|}
\hline Methods & RCT with increased dietary omega 6:omega 3 ratio. Study was conducted in the UK \\
\hline Participants & $\begin{array}{l}157 \text { men and women between the age of } 35 \text { to } 65 \text { years and a BMI between } 25 \text { and } 40 \\
\mathrm{~kg} / \mathrm{m}^{2} \text { were recruited from the community. } \\
\text { Inclusion criteria: } \\
\text { - BMI between } 25 \text { and } 40 \mathrm{~kg} / \mathrm{m}^{2} \text {. } \\
\text { - Between } 35 \text { and } 65 \text { years old. } \\
\text { - Not taking regular oil supplements. } \\
\text { - Not currently prescribed non-steroidal anti-inflammatory drugs, aspirin, steroids, } \\
\text { immunosuppressants, or lipid lowering drugs. } \\
\text { - No known diagnosis of diabetes, hypertension, hyperlipidaemia, asthma, or } \\
\text { chronic inflammatory disease. } \\
\text { - Not known or planned pregnancy. }\end{array}$ \\
\hline Interventions & $\begin{array}{l}\text { Intervention: } \\
\text { - Low n-3 (high LA:LNA): (white fish/sunflower, } \mathrm{N}=30,33 \% \text { males): white fish } \\
\text { and fat spreads and oils. LA:LNA was 27:1 for sunflower spread, and 63:0.1 for } \\
\text { sunflower oil. } \\
\text { - The fish was obtained from local supermarkets and volunteers selected items from } \\
\text { a range, including frozen fish, fishcakes, and tinned fish. The spreads and oils were } \\
\text { generously provided by Matthews Foods PLC. (Ossett, West Yorkshire, UK). } \\
\text { Control (N = 34, 34\% males): } \\
\text { - No intervention } \\
\text { Follow-up: } 24 \text { weeks }\end{array}$ \\
\hline Outcomes & Blood pressure and lipid levels \\
\hline Notes & $\begin{array}{l}\text { This was a 5-arm study: High n-3 (high LA:LNA), High n-3 (low LA:LNA), Low n-3 } \\
\text { (high LA:LNA), Low n-3 (low LA:LNA), and control. We used just the Low n-3 (high } \\
\text { LA:LNA), and control arms only hence total number randomised was } 64 \text { participants } \\
\text { The control group N was divided in } 2 \text { in the meta-analyses to prevent double counting } \\
\text { Funding source: This study was supported by funding from the UK Food Standards } \\
\text { Agency and Medical Research Council }\end{array}$ \\
\hline
\end{tabular}

\section{Risk of bias}

Minimization was used to assign subjects to a control group or one of four parallel intervention groups and to ensure that the treatment arms were balanced for age, BMI, gender, and habitual consumption of oily 
Moore 2006 High LA (Continued)

fish based on three categories $(0, \leq 1$, or $>$ 1 portion/week)

\begin{tabular}{|c|c|c|}
\hline Allocation concealment (selection bias) & Unclear risk & Not stated. \\
\hline $\begin{array}{l}\text { Blinding of participants and personnel } \\
\text { (performance bias) } \\
\text { All outcomes }\end{array}$ & High risk & $\begin{array}{l}\text { Due to the nature of food-based interven- } \\
\text { tions, it was not possible for the principal } \\
\text { investigators or subjects to be blinded to } \\
\text { the randomisation }\end{array}$ \\
\hline $\begin{array}{l}\text { Blinding of outcome assessment (detection } \\
\text { bias) } \\
\text { All outcomes }\end{array}$ & Low risk & $\begin{array}{l}\text { Laboratory analysts, dietary coders, clinical } \\
\text { scientists, and statisticians involved in the } \\
\text { study were blinded to the randomisation }\end{array}$ \\
\hline $\begin{array}{l}\text { Incomplete outcome data (attrition bias) } \\
\text { All outcomes }\end{array}$ & Low risk & $\begin{array}{l}\text { Number of drop-outs was specified and rea- } \\
\text { sons provided. }\end{array}$ \\
\hline Selective reporting (reporting bias) & Low risk & All outcomes stated were reported. \\
\hline Other bias & Low risk & $\begin{array}{l}\text { Not underpowered, baseline characteristics } \\
\text { are comparable, and the study was not in- } \\
\text { dustry funded }\end{array}$ \\
\hline
\end{tabular}

Moore 2006 Low LA

Methods

Participants
RCT with decreased dietary omega 6:omega 3 ratio. Study was conducted in the UK

157 men and women between the age of 35 to 65 years and a BMI between 25 and 40 $\mathrm{kg} / \mathrm{m}^{2}$ were recruited from the community Inclusion criteria:

- BMI between 25 and $40 \mathrm{~kg} / \mathrm{m}^{2}$.

- Between 35 and 65 years old.

- Not taking regular oil supplements.

- Not currently prescribed non-steroidal anti-inflammatory drugs, aspirin, steroids, immunosuppressants, or lipid lowering drugs.

- No known diagnosis of diabetes, hypertension, hyperlipidaemia, asthma, or chronic inflammatory disease.

- Not known or planned pregnancy.

Interventions

Intervention:

- Low n-3 (low LA:LNA): (white fish/rapeseed, $\mathrm{N}=29,38 \%$ males): white fish and fat spreads and oils. LA:LNA was 3:1 for rapeseed spread, and 2:1 for rapeseed oil.

- The fish was obtained from local supermarkets and volunteers selected items from a range, including frozen fish, fishcakes, and tinned fish. The spreads and oils were generously provided byMatthews Foods Plc. (Ossett, West Yorkshire, UK). Control ( $\mathrm{N}=34,34 \%$ males):

- No intervention.

Follow-up: 24 weeks 
Moore 2006 Low LA (Continued)

\begin{tabular}{ll}
\hline Outcomes & Blood pressure and lipid levels \\
\hline Notes & $\begin{array}{l}\text { This was a 5-arm study: High n-3 (high LA:LNA), High n-3 (low LA:LNA), Low n-3 } \\
\text { (high LA:LNA), Low n-3 (low LA:LNA), and control. We used just the Low n-3 (low } \\
\text { LA:LNA), and control arms only and control arms only hence total number randomised } \\
\text { was } 63 \text { participants } \\
\text { The control group N was divided in } 2 \text { in the meta-analyses to prevent double counting } \\
\text { Funding source: This study was supported by funding from the UK Food Standards } \\
\text { Agency and Medical Research Council }\end{array}$ \\
\hline
\end{tabular}

Risk of bias

\begin{tabular}{|c|c|c|}
\hline Bias & Authors' judgement & Support for judgement \\
\hline $\begin{array}{l}\text { Random sequence generation (selection } \\
\text { bias) }\end{array}$ & Unclear risk & As above (Moore 2006 High LA). \\
\hline Allocation concealment (selection bias) & Unclear risk & As above (Moore 2006 High LA). \\
\hline $\begin{array}{l}\text { Blinding of participants and personnel } \\
\text { (performance bias) } \\
\text { All outcomes }\end{array}$ & High risk & As above (Moore 2006 High LA). \\
\hline $\begin{array}{l}\text { Blinding of outcome assessment (detection } \\
\text { bias) } \\
\text { All outcomes }\end{array}$ & Low risk & As above (Moore 2006 High LA). \\
\hline $\begin{array}{l}\text { Incomplete outcome data (attrition bias) } \\
\text { All outcomes }\end{array}$ & Low risk & As above (Moore 2006 High LA). \\
\hline Selective reporting (reporting bias) & Low risk & As above (Moore 2006 High LA). \\
\hline Other bias & Low risk & As above (Moore 2006 High LA). \\
\hline
\end{tabular}

\section{OPTILIP 2006}

Methods

Participants
RCT with decreased omega 6 fats. Study was conducted in the UK

OPTILIP study. 258 men and postmenopausal women aged 45 to 70 years were recruited from general practices participating in the UK Medical Research Council General Practice Research Framework. Staff of King's College London and its associated hospitals were also recruited for this study

Inclusion criteria:

- Both genders.

- Postmenopausal (aged 45 to 70) women. In the younger subjects, postmenopausal status defined as a span of $\geq 1$ year since menstruation and was confirmed by measurement of the serum concentration of follicle-stimulating hormone.

- Subjects taking blood pressure or lipid-lowering medication were eligible if their 
medication regimens were stable.

Exclusion criteria:

- $\mathrm{BMI}<20$ or $>35 \mathrm{~kg} / \mathrm{m}^{2}$.

- Fasting serum cholesterol $>8 \mathrm{mmol} / \mathrm{L}$ or triacylglycerol $>6.0 \mathrm{mmol} / \mathrm{L}$.

- Abnormal liver function or hematology.

- Clinical history of cholestatic liver disease, pancreatitis, diabetes mellitus, or myocardial infarction.

- Current use of anticoagulants (excluding aspirin).

Interventions

Intervention ( $\mathrm{N}=49,63 \%$ males):

- Moderate linolenate diet where participants were provided with oils and spreads for the duration of the study. The LA and ALA contents of the spreads were 4.7 and 0 . $8 \mathrm{~g} / 100 \mathrm{~g}$. The LA and ALA contents of rapeseed (canola) oil were $19.7 \mathrm{~g}$ and $8.9 \mathrm{~g} /$ $100 \mathrm{~g}$. Particpants were also provided with 2 small cans of tuna/week, the tuna was canned in high linoleic sunflower oil.

- The diet was designed to keep the intake of saturated and monounsaturated fatty acids constant and to provide $-6 \%$ of energy from PUFAs.

Control ( $\mathrm{N}=44,68 \%$ males):

- Participants were provided with oils and spreads for the duration of the study. The LA and ALA contents of the spreads were $39.6 \mathrm{~g}$ and $0.5 \mathrm{~g} / 100 \mathrm{~g}$. The LA and ALA contents of high-oleic sunflower oil were $10.6 \mathrm{~g}$ and $0.3 \mathrm{~g} / 100 \mathrm{~g}$. Particpants were also provided with 2 small cans of tuna/week, the tuna was canned in olive oil.

- The diet was designed to keep the intake of saturated and monounsaturated fatty acids constant and to provide $-6 \%$ of energy from PUFAs.

Follow-up: 24 weeks

Outcomes Lipid levels

Notes

The Quantification of the Optimal n6/n3 ratio in the UK Diet (OPTILIP) Study was designed to assess the effects of lowering the dietary n6:n3 on CVD risk factors in older people. The objective was achieved by using a food-based intervention that involved increasing the relative intake of linolenic acid or n3 LC-PUFAs (notably EPA and DHA) , or both, in relation to the intake of linoleic acid. This was a 5-arm study: n-3 LC-PUFA + linolenate, n-3 LC-PUFA, moderate linolenate diet, high linolenate, and control. We used just the moderate linolenate (lower omega 6) and control arms (higher omega 6) hence total number randomised was 93 participants

Funding source: Supported by the UK Food Standards Agency. Unilever Research, and Mills DA, Norway, provided the spreads and the salmon spread, respectively

Risk of bias

Bias

Random sequence generation (selection Unclear risk bias)
Unclear risk

\section{Support for judgement}

Not stated.
Not stated. "Subjects were randomly assigned to 1 of 5 diets; subjects living together were allocated to the same treat- 


\begin{tabular}{l|l|l}
\hline $\begin{array}{l}\text { Blinding of participants and personnel } \\
\text { (performance bias) }\end{array}$ & Not stated. \\
\hline All outcomes & & \\
\hline
\end{tabular}

Blinding of outcome assessment (detection Unclear risk bias)

All outcomes

Incomplete outcome data (attrition bias) Unclear risk All outcomes

\begin{tabular}{|c|c|c|}
\hline Selective reporting (reporting bias) & Low risk & All outcomes stated were reported. \\
\hline Other bias & Unclear risk & $\begin{array}{l}\text { Insufficient information to judge. How- } \\
\text { ever, the study participants received a mod- } \\
\text { est financial reimbursement for their par- } \\
\text { ticipation in the study. They were provided } \\
\text { at regular intervals with some foods (yellow } \\
\text { fat spreads (i.e. butter, margarine, and low- } \\
\text { fat spreads), oil, and fish) for the dietary } \\
\text { intervention period }\end{array}$ \\
\hline
\end{tabular}

Details of withdrawals and lost to follow-up were stated but not per study arm. Flow diagram was not provided. ITT analysis was not used

\section{Not stated.}

\section{Sarkkinen 1998}

\begin{tabular}{ll} 
Methods & RCT with increased omega 6 fats. Study was conducted in Finland \\
\hline Participants & $\begin{array}{l}160 \text { men and women aged } 23 \text { to } 58 \text { years old with hypercholesterolemia were recruited } \\
\text { through the occupational health care system in the area of Kuopio in Eastern Finland } \\
\text { Inclusion criteria: } \\
\text { - Mild to moderate hypercholesterolaemia. } \\
\text { - Serum total cholesterol between } 6.5 \text { and } 8.0 \mathrm{mmol} / \mathrm{L} \text { before the study. } \\
\text { Exclusion criteria: } \\
\text { - Known diseases affecting serum lipid levels. } \\
\text { - Irregular eating patterns. } \\
\text { - Excess consumption of alcohol }(>45 \mathrm{~g} \text { ethanol/d). }\end{array}$ \\
\hline
\end{tabular}
received detailed written instructions on diet at their own energy level. The goal was to consume $30 \%$ of energy from fat (10\% saturated fat, $10 \%$ monosaturated fat, $10 \%$ polyunsaturated fat), $15 \%$ of energy from protein, $55 \%$ of energy from carbohydrate, and 15 to $20 \mathrm{~g}$ of fibre per day. The diet composed of normal food items, substituting low-fat items for high-fat foods typically consumed in the Finnish diet; fatty acid composition was adjusted by changing quality and quantity of fat spreads. Sunflower oil margarine and sunflower oil were provided

Control ( $\mathrm{N}=36,47 \%$ males): High fat, saturated fat-enriched control diet: participants 
received detailed written instructions on diet at their own energy level. The goal was to consume $38 \%$ of energy from fat (18\% saturated fat, $15 \%$ monosaturated fat, $5 \%$ polyunsaturated fat), $15 \%$ of energy from protein, $47 \%$ of energy from carbohydrate, and 15 to $20 \mathrm{~g}$ of fibre per day. The diet composed of normal food items, substituting low-fat items for high-fat foods typically consumed in the Finnish diet; fatty acid composition was adjusted by changing quality and quantity of fat spreads and subjects received detailed written instructions on the diets at their own energy level. Butter and a small amount of low-erucic acid rapeseed oil were provided

Follow-up: 24 weeks

\begin{tabular}{ll}
\hline Outcomes & Lipid levels \\
\hline Notes & $\begin{array}{l}\text { This is a 4-arm study: High fat, saturated fat enriched (control), reduced-fat sunflower } \\
\text { oil-enriched, reduced-fat rapeseed oil-enriched, and reduced-fat arm. We used just the } \\
\text { control and reduced-fat sunflower oil-enriched arms only hence total number randomised } \\
\text { was } 73 \text { participants } \\
\text { Funding source: Supported by grants from the Finnish Food Research Foundation, } \\
\text { Finnish Heart Research Foundation, Aarne and Aili Turunen Foundation, and the Re- } \\
\text { search Council for Health, Academy of Finland }\end{array}$ \\
\hline
\end{tabular}

\section{Risk of bias}

\begin{tabular}{|c|c|c|}
\hline Bias & Authors' judgement & Support for judgement \\
\hline $\begin{array}{l}\text { Random sequence generation (selection } \\
\text { bias) }\end{array}$ & Unclear risk & Not stated. \\
\hline Allocation concealment (selection bias) & Unclear risk & Not stated. \\
\hline $\begin{array}{l}\text { Blinding of participants and personnel } \\
\text { (performance bias) } \\
\text { All outcomes }\end{array}$ & Unclear risk & $\begin{array}{l}\text { Spreads provided on a single-blind basis but } \\
\text { no other details provided }\end{array}$ \\
\hline $\begin{array}{l}\text { Blinding of outcome assessment (detection } \\
\text { bias) } \\
\text { All outcomes }\end{array}$ & Unclear risk & Not stated. \\
\hline $\begin{array}{l}\text { Incomplete outcome data (attrition bias) } \\
\text { All outcomes }\end{array}$ & Unclear risk & $\begin{array}{l}\text { Details of withdrawals and lost to follow-up } \\
\text { were stated but not per study arm. Flow di- } \\
\text { agram was not provided. ITT analysis was } \\
\text { not used }\end{array}$ \\
\hline Selective reporting (reporting bias) & Low risk & All outcomes stated were reported. \\
\hline Other bias & Unclear risk & $\begin{array}{l}\text { Insufficient information to judge. Power } \\
\text { calculation was not carried out. Non-in- } \\
\text { dustrial funding }\end{array}$ \\
\hline
\end{tabular}


Sluijs 2010

Methods

RCT with increased omega 6 supplementation (cis-9,trans-11 conjugated linoleic acid) . Study was conducted in the Netherlands

Participants

401 men and women between the age of 40 to 70 years old and BMI $\geq 25 \mathrm{~kg} / \mathrm{m}^{2}$ were recruited through the Julius Center "POKA" database municipal registers of a large and middle-large town in the middle part of the Netherlands

Inclusion criteria:

- Apparently healthy men and women

- Aged 40 to 70 years

- $\mathrm{BMI} \geq 25 \mathrm{~kg} / \mathrm{m}^{2}$

Interventions

Intervention: High omega 6 ( 4 g CLA/d, N = 201, 48\% males): The c9, $t 11$ CLA oil was manufactured from safflower oil. Four capsules of $1 \mathrm{~g}$ oil each were taken daily. CLA capsules provided $80 \%$ CLA isomers, of which $80 \%(2.5 \mathrm{~g} / \mathrm{d})$ was $c 9, t 11$ CLA and $20 \%$ $(0.6 \mathrm{~g} / \mathrm{d})$ was $t 10, c 12$ CLA. The percentage of energy provided by $c 9, t 11$ CLA and $t 10$, $c 12$ CLA during the intervention was around $1 \%$ and around $0.3 \%$, respectively (based on a daily intake of 2000 to $2500 \mathrm{kcal}$ )

Control ( $\mathrm{N}=200,48.6 \%$ males): Placebo capsules contained an equal amount of fat and were composed of a blend of palm oil ( $80 \%)$ and soybean oil $(20 \%)$, which resembles the average fatty acid composition of the fat consumed by a Western population Follow-up: 24 weeks

\begin{tabular}{ll} 
Outcomes $\quad$ Blood pressure and lipid levels \\
\hline
\end{tabular}

Notes

Funding source: Supported by a grant from the Dutch Ministry of Economic Affairs and by a grant from Lipid Nutrition BV, Wormerveer, Netherlands. Lipid Nutrition is a commercial company focused on developing and producing specialty fats and oils

Risk of bias

Bias

Random sequence generation (selection Unclear risk bias)
Authors' judgement
Potential par-

ticipants were recruited through a random selection from the municipal registers of a large and middle-large town in the middle part of the Netherlands. Minimisation was used to assign subjects to a control group or intervention group in a $1: 1$ ratio. Randomisation was stratified for sex

Not stated.

Allocation concealment (selection bias) Unclear risk

Blinded study capsules were supplied in individual, pre-prepared, numbered bottles. The investigators were unaware of treatment allocations for the study duration

Omega 6 fatty acids for the primary prevention of cardiovascular disease (Review) 
Sluijs 2010 (Continued)

\begin{tabular}{|c|c|c|}
\hline $\begin{array}{l}\text { Blinding of outcome assessment (detection } \\
\text { bias) } \\
\text { All outcomes }\end{array}$ & Unclear risk & Not stated. \\
\hline $\begin{array}{l}\text { Incomplete outcome data (attrition bias) } \\
\text { All outcomes }\end{array}$ & Low risk & $\begin{array}{l}\text { Number of drop-outs was specified and rea- } \\
\text { sons provided. }\end{array}$ \\
\hline Selective reporting (reporting bias) & Unclear risk & All outcomes stated were reported. \\
\hline Other bias & Unclear risk & $\begin{array}{l}\text { Not underpowered, baseline characteristics } \\
\text { were similar between the two groups. The } \\
\text { study was partially funded by commercial } \\
\text { funds }\end{array}$ \\
\hline
\end{tabular}

Characteristics of excluded studies [ordered by study ID]

\begin{tabular}{|c|c|}
\hline Study & Reason for exclusion \\
\hline Ahrén 2009 & Control not minimal and short term trial (12 weeks). \\
\hline Allman-Farinelli 1999 & Control not minimal and short term trial (6 weeks). \\
\hline Anderson 1957 & Short term trial (less than 4 weeks). \\
\hline Angela Liou 2009 & Short term trial ( 8 weeks). \\
\hline Bachmair 2012 & Control not minimal, irrelevant outcomes and short term trial (3 months) \\
\hline Becker 1983 & Control not minimal and short term trial ( 4 weeks). \\
\hline Belury 2009 & Control not minimal, participants irrelevant and short term trial (16 weeks) \\
\hline Bemelmans 2000 & Control not minimal (comparison against omega 3 intakes). \\
\hline Bemelmans 2004 & Control not minimal (comparison against omega 3 intakes). \\
\hline Benito 2001 & Control not minimal and short term trial (93 days). \\
\hline Bermejo 2012 & Intervention irrelevant and short term trial (12 weeks). \\
\hline Bjermo 2012 & Short term trial ( 10 weeks). \\
\hline Blair 1993 & Irrelevant outcomes and short term trial (100 days). \\
\hline Boberg 1986 & Short term trial (8 weeks). \\
\hline
\end{tabular}


(Continued)

\begin{tabular}{|c|c|}
\hline Bonanome 1992 & Control not minimal and short term (3 weeks). \\
\hline Bouwens 2009 & $\begin{array}{l}\text { Control not minimal (comparison against omega } 3 \text { intakes or low omega } 3 \text { intakes but with a similar } \\
\text { omega } 6 \text { content) }\end{array}$ \\
\hline Brady 2004 & Short term trial ( 12 weeks). \\
\hline Bramkamp 1974 & Not a RCT. \\
\hline Bronsgeest-Schoute 1979 & Control not minimal and short term trial (6 weeks). \\
\hline Brox 1981 & Control not minimal and short term trial (6 weeks). \\
\hline Burdge 2004 & Intervention, control and outcomes irrelevant and short term trial ( 8 weeks) \\
\hline Camargo 2013 & Intervention and control irrelevant and short term trial ( 12 weeks) \\
\hline Carvalho 2012 & Short term trial (90 days). \\
\hline Cater 1997 & Control not minimal and short term trial (3 weeks). \\
\hline Clandinin 1999 & Short term trial ( 21 days). \\
\hline Dayton 1962 & Irrelevant intervention. \\
\hline de Kok 2003 & Irrelevant outcomes and short term trial (6 weeks). \\
\hline Deferne 1992 & Control not minimal and short term trial (9 weeks). \\
\hline Dembinska-Kiec 2010 & Not a RCT. \\
\hline Dembinska-Kiec 2011 & Not a RCT. \\
\hline Elisha 2011 & Not a RCT. \\
\hline Failor 1988 & Not a RCT and short term trial (3 weeks). \\
\hline Finnegan 2003a & Irrelevant outcomes and control not minimal. \\
\hline Finnegan 2003b & Irrelevant intervention. \\
\hline Friday 1991 & Not a RCT and short term trial (3 weeks). \\
\hline Gaullier 2004 & Irrelevant intervention. \\
\hline Gaullier 2005 & Not a RCT and control irrelevant. \\
\hline Gaullier 2007 & Irrelevant intervention. \\
\hline
\end{tabular}


(Continued)

\begin{tabular}{|c|c|}
\hline Ghafoorunissa 1995 & Control not minimal and short term trial (8 weeks). \\
\hline Ghafoorunissa 2002 & Not a RCT. \\
\hline Giacco 2007 & Intervention and control irrelevant and short term trial ( 3 months) \\
\hline Groen 1965 & Short term trial ( 5 weeks). \\
\hline Grundt 1995 & Intervention and control irrelevant and short term trial ( 12 weeks) \\
\hline Grønn 1991 & Not a RCT and short term trial (8 weeks). \\
\hline Haglund 1998 & Control not minimal and short term trial ( 4 weeks). \\
\hline Harris 2009 & Not a RCT. \\
\hline Hartwich 2009 & Control not minimal and short term trial (12 weeks). \\
\hline Hartwich 2010 & Control not minimal and short term trial (8 hours). \\
\hline Heine 1989 & Irrelevant participants. \\
\hline Higdon 2000 & Short term intervention ( 5 weeks). \\
\hline Higdon 2001 & Short term intervention ( 5 weeks). \\
\hline Ho 1999 & Irrelevant outcomes, control not minimal and short term trial (12 weeks) \\
\hline Hodson 2001 & Control not minimal and short term trial (2.5 weeks). \\
\hline Hui 1989 & Intervention in rats. \\
\hline Hwang 1997 & Short term trial (12 weeks). \\
\hline Intorre 2013 & Short term trial ( 4 weeks). \\
\hline Iwata 2007 & Control not minimal and short term trial (12 weeks). \\
\hline Khan 2003 & Irrelevant outcomes. \\
\hline Kiecolt-Glaser 2013 & Irrelevant intervention and outcomes and short term trial ( 4 months) \\
\hline Kim 2009 & Irrelevant intervention and short term trial ( 12 weeks). \\
\hline Kingsbury 1961 & Control not minimal and short term trial (6 weeks). \\
\hline Knapp 1989 & Short term trial (3 months). \\
\hline
\end{tabular}


(Continued)

\begin{tabular}{|c|c|}
\hline Koyama 2009 & Not a RCT and short term trial (8 weeks). \\
\hline Lambert 2007 & Short term trial (12 weeks). \\
\hline Lands 1992 & Not a RCT. \\
\hline Lee 2012 & Short term trial ( 4 weeks). \\
\hline Legrand 2010 & Control not minimal and short term trial (90 days). \\
\hline MARGARIN 2002 & Irrelevant intervention. \\
\hline Margolin 1990 & Control not minimal and short term intervention (8 weeks). \\
\hline Margolin 1991 & Control not minimal and short term intervention (8 weeks). \\
\hline McDaniel 2010 & Irrelevant outcomes and short term trial ( 4 weeks). \\
\hline Mendis 2001 & Irrelevant intervention. \\
\hline Miles 2004 & Control not minimal, irrelevant outcomes and short term trial ( 12 weeks) \\
\hline Mills 1989 & Short term trial ( 28 days). \\
\hline Minihane 2005 & Control not minimal and short term trial (6 weeks). \\
\hline Misikangas 2001 & Irrelevant outcomes and short term trial (6 weeks). \\
\hline Mortensen 1983 & Control not minimal and short term trial ( 4 weeks). \\
\hline Møller 1992 & Control not minimal and short term trial ( 1 day). \\
\hline Naber 1992 & Short term trial (12 weeks). \\
\hline Naumann 2006 & Sort term trial (13 weeks). \\
\hline Nelson $1997 \mathrm{a}$ & Short term trial (50 days). \\
\hline Nelson $1997 \mathrm{~b}$ & Short term trial ( 65 days). \\
\hline Nestel 1992 & Control not minimal and short term intervention ( 4 weeks). \\
\hline Nestel 1995 & Control not minimal and short term trial (3 weeks). \\
\hline Noakes 1996 & Control not minimal and short term trial (11 weeks). \\
\hline Oe 2008 & Short term trial (3 months). \\
\hline
\end{tabular}


(Continued)

\begin{tabular}{|c|c|}
\hline Paschos 2007 & Control not minimal and short term trial (12 weeks). \\
\hline Pał kowska 2012 & Short term trial (12 weeks). \\
\hline Perez-Martinez 2010 & Irrelevant intervention, control and outcomes and short term trial (12 weeks) \\
\hline Perkins 1958 & Short term trial (7 weeks). \\
\hline Radack 1990 & Control not minimal and short term trial (8 weeks). \\
\hline Radack 1991 & Control not minimal and short term trial (12 weeks). \\
\hline Rajaram 2012 & Intervention irrelevant, irrelevant outcomes and short term trial (8 weeks) \\
\hline Rallidis 2003 & Control not minimal and short term trial (3 months). \\
\hline Rallidis 2004 & Control not minimal and short term trial (12 weeks). \\
\hline Ramprasath 2012 & Short term trial (20 days). \\
\hline Reaven 1991 & Short term trial ( 5 weeks). \\
\hline Risérus 2002a & Irrelevant intervention and short term trial ( 12 weeks). \\
\hline Risérus 2002b & Irrelevant intervention and short term trial ( 12 weeks). \\
\hline Risérus 2004 & Irrelevant intervention and short term trial ( 12 weeks). \\
\hline Robertson 2002 & Control not minimal and short term trial (1 day). \\
\hline Roche 2009 & Intervention and control irrelevant. \\
\hline Sanders 1983 & Intervention irrelevant and short term trial ( 2 weeks). \\
\hline Sanders 1997 & Control not minimal and short term trial (21 days). \\
\hline Singer 1991 & Control not minimal and short term trial ( 3 months). \\
\hline Sirtori 1992 & Short term trial ( 6 weeks). \\
\hline Smedman 2001 & Short term trial (12 weeks). \\
\hline Sofi 2010 & Not a RCT and short term trial ( 10 weeks). \\
\hline Sofi 2013 & Intervention and control irrelevant and short term trial ( 10 weeks) \\
\hline Solà 1997 & Control not minimal and short term trial (8 weeks). \\
\hline
\end{tabular}

Omega 6 fatty acids for the primary prevention of cardiovascular disease (Review) 
(Continued)

\begin{tabular}{|c|c|}
\hline Song 2005 & Control not minimal and short term trial (12 weeks). \\
\hline Steck 2007 & Control not minimal and short term trial (12 weeks). \\
\hline Sundram 1992 & Short term trial (6 weeks). \\
\hline Svaneborg 1994 & Control not minimal and short term trial (1 day). \\
\hline Tavakkoli 2010 & Control not minimal and short term trial (12 weeks). \\
\hline Taylor 2006 & Short term trial (12 weeks). \\
\hline Tholstrup 2008 & Irrelevant intervention and short term trial (16 weeks). \\
\hline Tierney 2011 & Intervention and control irrelevant and short term trial ( 12 weeks) \\
\hline Truswell 2000 & Short term trial (3 to 5 weeks). \\
\hline Tsai 1997 & Irrelevant control and short term trial (6 weeks). \\
\hline Tsofliou 2009 & Intervention irrelevant and short term trial (12 weeks). \\
\hline Tulk 2009 & No relevant outcomes and short term trial (8 hours). \\
\hline Valsta 1996 & Control not minimal, intervention irrelevant and short term trial ( 6 weeks) \\
\hline Venter 1988 & Short term trial (12 weeks). \\
\hline Vergroesen 1980 & Not a RCT. \\
\hline Vericel 1987 & Control not minimal and short term trial (2 months). \\
\hline Vermunt 2001 & Short term trial (6 weeks). \\
\hline Viikari 1986 & Not a RCT and short term trial ( 3 months). \\
\hline West 2010 & Short term trial (18 weeks). \\
\hline Wilkinson 2005 & Control not minimal and short term trial (12 weeks). \\
\hline Yam 2001 & Participants irrelevant and short term trial (12 weeks). \\
\hline Zhao 2004 & Short term (6 weeks). \\
\hline Zhao 2007 & No relevant outcomes and short term trial (6 weeks). \\
\hline
\end{tabular}

Omega 6 fatty acids for the primary prevention of cardiovascular disease (Review) 


\section{Characteristics of studies awaiting assessment [ordered by study ID]}

\section{Natvig 1967 High LA}

\begin{tabular}{|c|c|}
\hline Methods & RCT with increased omega- 6 fats \\
\hline Participants & 16,615 men aged 50 to 59 years working in industrial and other firms in different parts of Norway \\
\hline Interventions & $\begin{array}{l}\text { Intervention: } \\
\text { - Sunflower oil: } 10 \mathrm{~mL} / \text { day with approximately } 63 \% \mathrm{LA} \\
\text { Control: } \\
\text { - Not given oil } \\
\text { Duration of the study: } \\
52 \text { weeks }\end{array}$ \\
\hline Outcomes & Morbidity and mortality of coronary and other vascular diseases \\
\hline Notes & 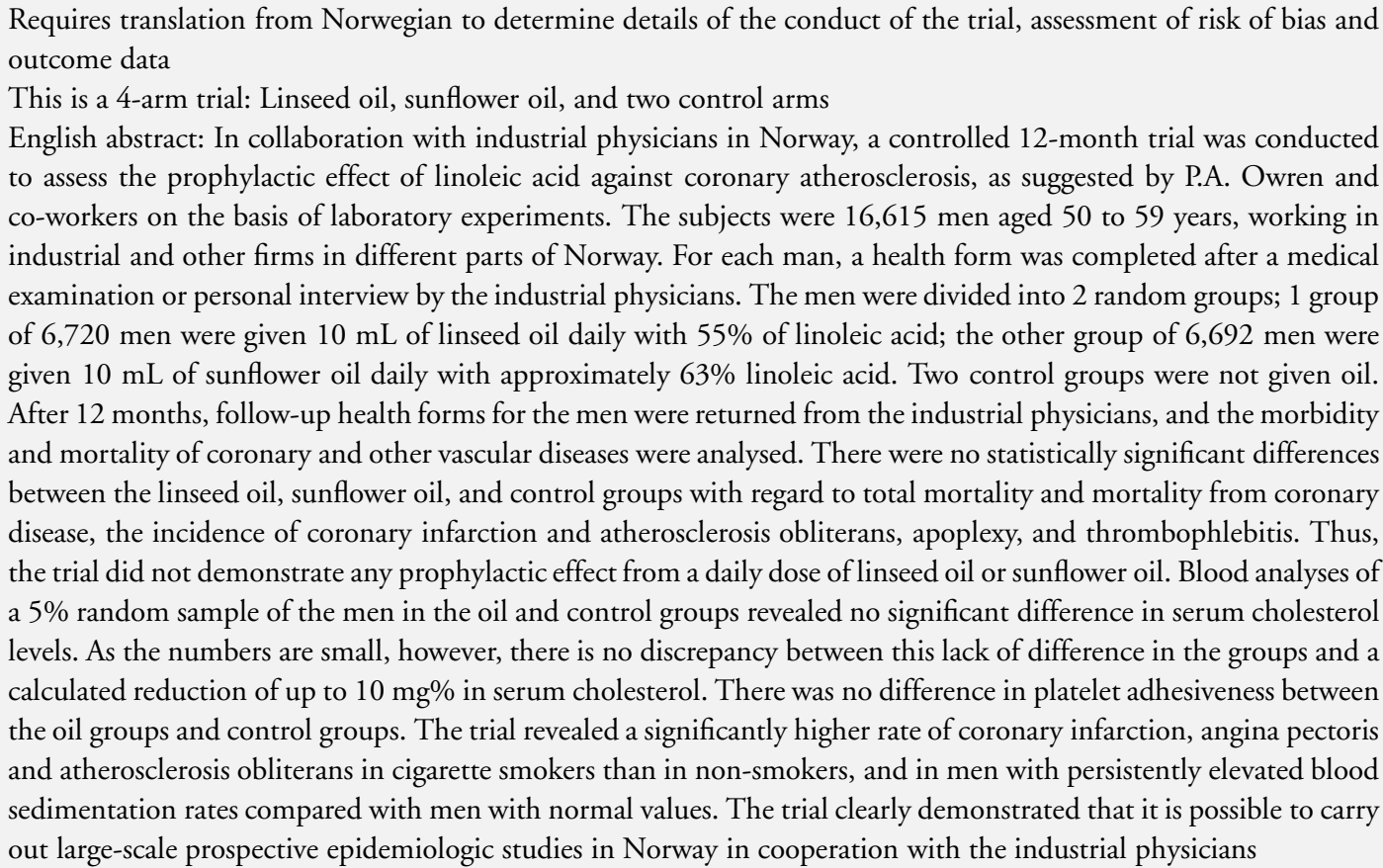 \\
\hline
\end{tabular}

Natvig 1967 Low LA

\begin{tabular}{|c|c|}
\hline Methods & RCT with decreased omega- 6 fats \\
\hline Participants & As above \\
\hline Interventions & $\begin{array}{l}\text { Intervention: } \\
\text { - Linseed oil: } 10 \mathrm{~mL} / \text { day with } 55 \% \text { of LA } \\
\text { Control: } \\
\text { - Not given oil }\end{array}$ \\
\hline
\end{tabular}

Omega 6 fatty acids for the primary prevention of cardiovascular disease (Review) 
Natvig 1967 Low LA (Continued)

Duration of the study: 52 weeks

\begin{tabular}{ll}
\hline Outcomes & As above \\
\hline Notes & As above \\
\hline
\end{tabular}

\section{Nordoy 1981}

\begin{tabular}{|c|c|}
\hline Methods & Cross over design - increased omega 6 fats \\
\hline Participants & 10 healthy male participants \\
\hline Interventions & $\begin{array}{l}\text { - } 25 \mathrm{~mL} \text { cod liver oil } \\
\text { - } 25 \mathrm{~mL} \text { corn oil } \\
\text { - Unclear if there was a control arm }\end{array}$ \\
\hline Outcomes & Not clear if secondary outcomes (lipid levels) were reported \\
\hline Notes & $\begin{array}{l}\text { Library unable to find. } \\
\text { Abstract: Ten healthy male subjects on an ordinary diet were given daily dietary supplement of } 25 \mathrm{~mL} \text { cod liver oil } \\
\text { (CLO) or corn oil (CO) for periods of } 6 \text { weeks in a crossover study. Significant changes were observed in the plasma } \\
\text { total fatty acid composition. The main platelet phospholipids fractions were also significantly altered, particularly by } \\
\text { CLO with an increase of the eicosapentaenoic acid (EPA): arachidonic acid (AA) ratio. Both supplements reduced } \\
\text { collagen induced platelet aggregation and TXB2 production, with CLO as the most potent one. No spontaneous } \\
\text { release of an anti-aggregatory substance or } 6 \text {-keto-PGF1 alpha from vein tissues were found, and the total urinary } \\
\text { excretion of prostaglandin metabolites (E and F series) remained unchanged }\end{array}$ \\
\hline
\end{tabular}

\section{Ryu 1999}

\begin{tabular}{ll}
\hline Methods & No information. \\
\hline Participants & No information. \\
\hline Interventions & No information. \\
\hline Outcomes & No information. \\
\hline Notes & Library unable to find. \\
\hline
\end{tabular}

\section{Singer 1993}

\begin{tabular}{l|l}
\hline Methods & No information. \\
\hline Participants & No information. \\
\hline Interventions & No information.
\end{tabular}




\section{Singer 1993 (Continued)}

Outcomes No information.

Notes Library unable to find. 
DATA AND ANALYSES

Comparison 1. Increased omega 6 versus control

\begin{tabular}{|c|c|c|c|c|}
\hline Outcome or subgroup title & $\begin{array}{l}\text { No. of } \\
\text { studies }\end{array}$ & $\begin{array}{c}\text { No. of } \\
\text { participants }\end{array}$ & Statistical method & Effect size \\
\hline $\begin{array}{l}1 \text { Systolic blood pressure, change } \\
\text { from baseline }\end{array}$ & 2 & 387 & Mean Difference (IV, Fixed, 95\% CI) & $-0.79[-1.00,1.41]$ \\
\hline $\begin{array}{l}2 \text { Diastolic blood pressure, change } \\
\text { from baseline }\end{array}$ & 2 & 387 & Mean Difference (IV, Fixed, 95\% CI) & $-0.02[-1.35,1.32]$ \\
\hline $\begin{array}{l}3 \text { Total cholesterol, change from } \\
\text { baseline }\end{array}$ & 3 & 460 & Mean Difference (IV, Fixed, 95\% CI) & $0.02[-0.13,0.18]$ \\
\hline $\begin{array}{l}4 \text { LDL cholesterol, change from } \\
\text { baseline }\end{array}$ & 3 & 460 & Mean Difference (IV, Fixed, 95\% CI) & $-0.01[-0.14,0.12]$ \\
\hline $\begin{array}{l}5 \text { HDL cholesterol, change from } \\
\text { baseline }\end{array}$ & 3 & 460 & Mean Difference (IV, Fixed, 95\% CI) & $0.01[-0.04,0.06]$ \\
\hline $\begin{array}{l}6 \text { Triglycerides, change from } \\
\text { baseline }\end{array}$ & 2 & 419 & Mean Difference (IV, Fixed, 95\% CI) & $0.03[-0.07,0.12]$ \\
\hline
\end{tabular}

\section{Comparison 2. Reduced omega 6 versus control}

\begin{tabular}{lcclc} 
Outcome or subgroup title & $\begin{array}{c}\text { No. of } \\
\text { studies }\end{array}$ & $\begin{array}{c}\text { No. of } \\
\text { participants }\end{array}$ & Statistical method & Effect size \\
\hline $\begin{array}{l}1 \text { Systolic blood pressure, change } \\
\text { from baseline }\end{array}$ & 1 & & Mean Difference (IV, Fixed, 95\% CI) & Totals not selected \\
$\begin{array}{l}2 \begin{array}{c}\text { Diastolic blood pressure, change } \\
\text { from baseline }\end{array} \\
\begin{array}{l}\text { Total cholesterol, change from } \\
\text { baseline [mmol/L] }\end{array}\end{array}$ & 1 & 114 & Std. Mean Difference (IV, Fixed, 95\% CI) & $0.06[-0.31,0.43]$ \\
$\begin{array}{l}4 \text { LDL cholesterol, change from } \\
\text { baseline }\end{array}$ & 2 & 114 & Mean Difference (IV, Fixed, 95\% CI) & -0.04 [-0.36, 0.29] \\
$\begin{array}{l}5 \text { HDL cholesterol, change from } \\
\text { baseline }\end{array}$ & 2 & 114 & Mean Difference (IV, Fixed, 95\% CI) & $-0.02[-0.16,0.12]$ \\
$\begin{array}{l}6 \text { Triglycerides, change from } \\
\text { baseline }\end{array}$ & 1 & & Mean Difference (IV, Fixed, 95\% CI) & Totals not selected \\
\hline
\end{tabular}




\section{Analysis I.I. Comparison I Increased omega 6 versus control, Outcome I Systolic blood pressure, change}

from baseline.

Review: Omega 6 fatty acids for the primary prevention of cardiovascular disease

Comparison: I Increased omega 6 versus control

Outcome: I Systolic blood pressure, change from baseline

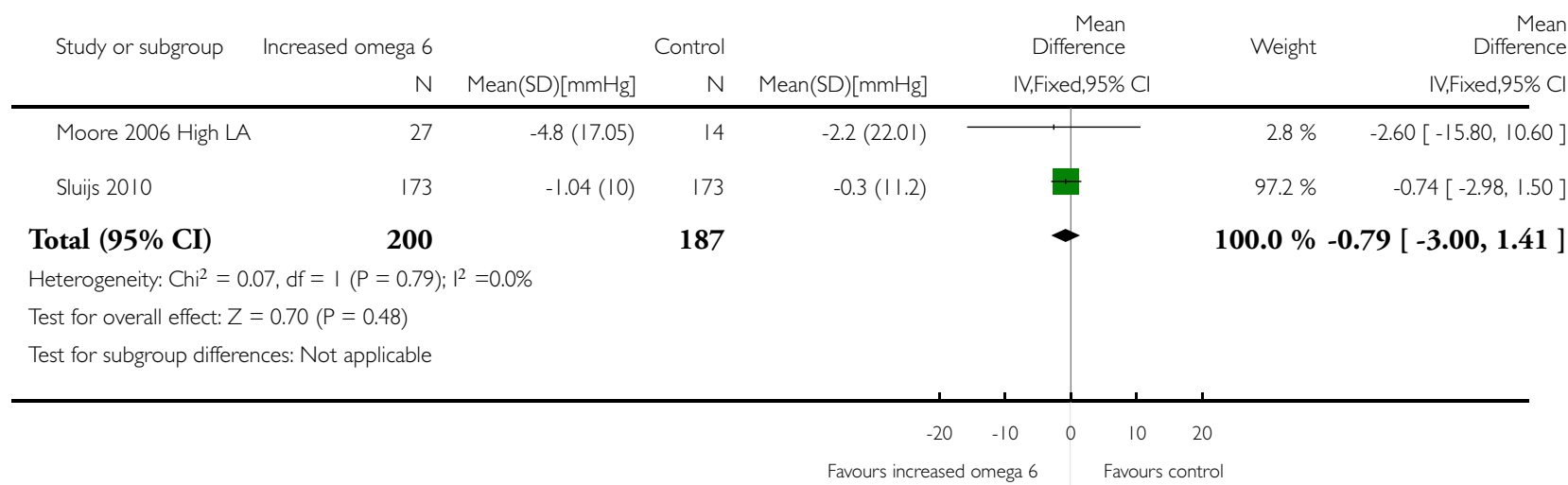

\section{Analysis I.2. Comparison I Increased omega 6 versus control, Outcome 2 Diastolic blood pressure, change} from baseline.

Review: Omega 6 fatty acids for the primary prevention of cardiovascular disease

Comparison: I Increased omega 6 versus control

Outcome: 2 Diastolic blood pressure, change from baseline

\begin{tabular}{|c|c|c|c|c|c|c|c|}
\hline \multirow[t]{2}{*}{ Study or subgroup } & Increased omega 6 & & Control & & $\begin{array}{l}\text { Mean } \\
\text { Difference }\end{array}$ & Weight & $\begin{array}{r}\text { Mean } \\
\text { Difference }\end{array}$ \\
\hline & $\mathrm{N}$ & Mean(SD) $[\mathrm{mmHg}]$ & $N$ & Mean(SD) $[\mathrm{mmHg}]$ & IV,Fixed,95\% Cl & & IV,Fixed,95\% Cl \\
\hline Moore 2006 High LA & 27 & $-5.1(10.79)$ & 14 & $-3.5(11.23)$ & \begin{tabular}{l|l} 
& \\
&
\end{tabular} & $3.5 \%$ & $-1.60[-8.75,5.55]$ \\
\hline Sluijs 2010 & 173 & $-0.21(6.6)$ & 173 & $-0.25(6.3)$ & & $96.5 \%$ & $0.04[-1.32,1.40]$ \\
\hline
\end{tabular}

Total (95\% CI)

200

187

$100.0 \%-0.02[-1.35,1.32]$

Heterogeneity: $\mathrm{Chi}^{2}=0.19, \mathrm{df}=\mathrm{I}(\mathrm{P}=0.66) ; \mathrm{I}^{2}=0.0 \%$

Test for overall effect: $Z=0.03(P=0.98)$

Test for subgroup differences: Not applicable

Favours increased omega $6 \quad$ Favours control 
Analysis I.3. Comparison I Increased omega 6 versus control, Outcome 3 Total cholesterol, change from baseline.

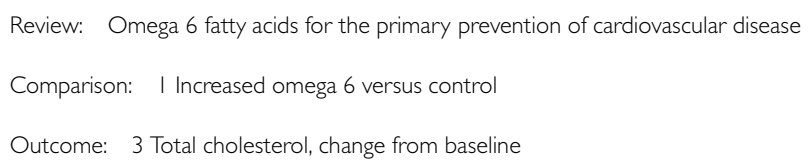

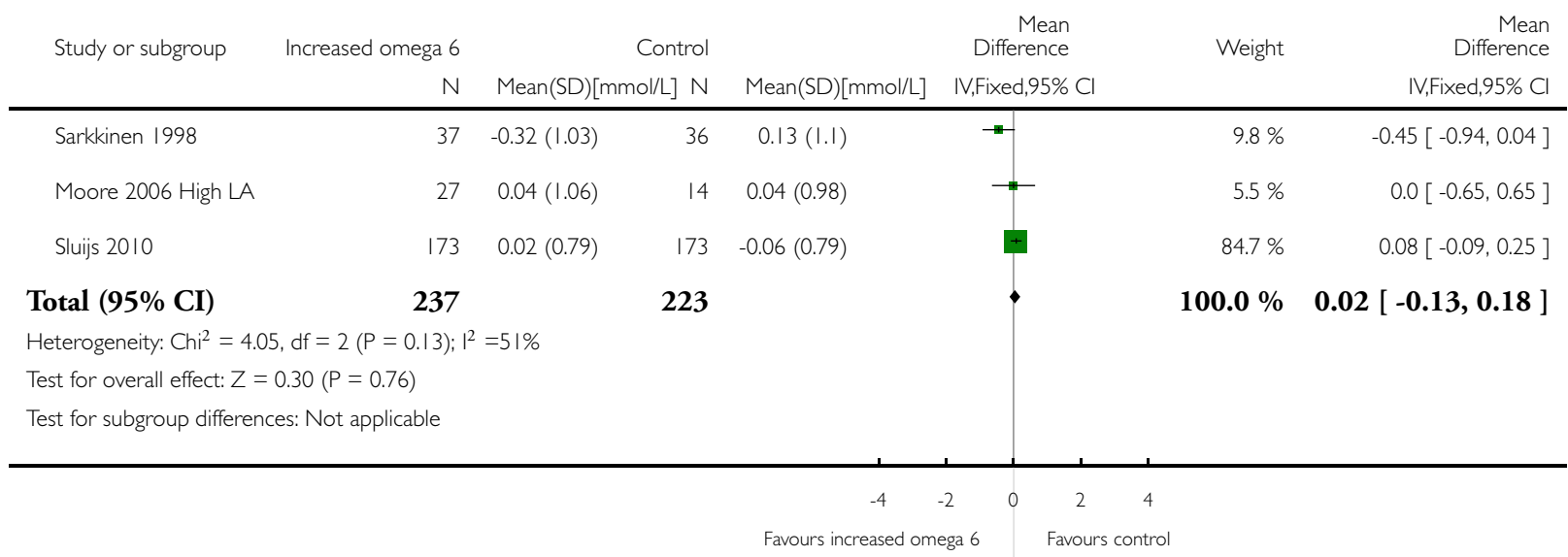


Analysis I.4. Comparison I Increased omega 6 versus control, Outcome 4 LDL cholesterol, change from baseline.

Review: Omega 6 fatty acids for the primary prevention of cardiovascular disease

Comparison: I Increased omega 6 versus control

Outcome: $4 \mathrm{LDL}$ cholesterol, change from baseline

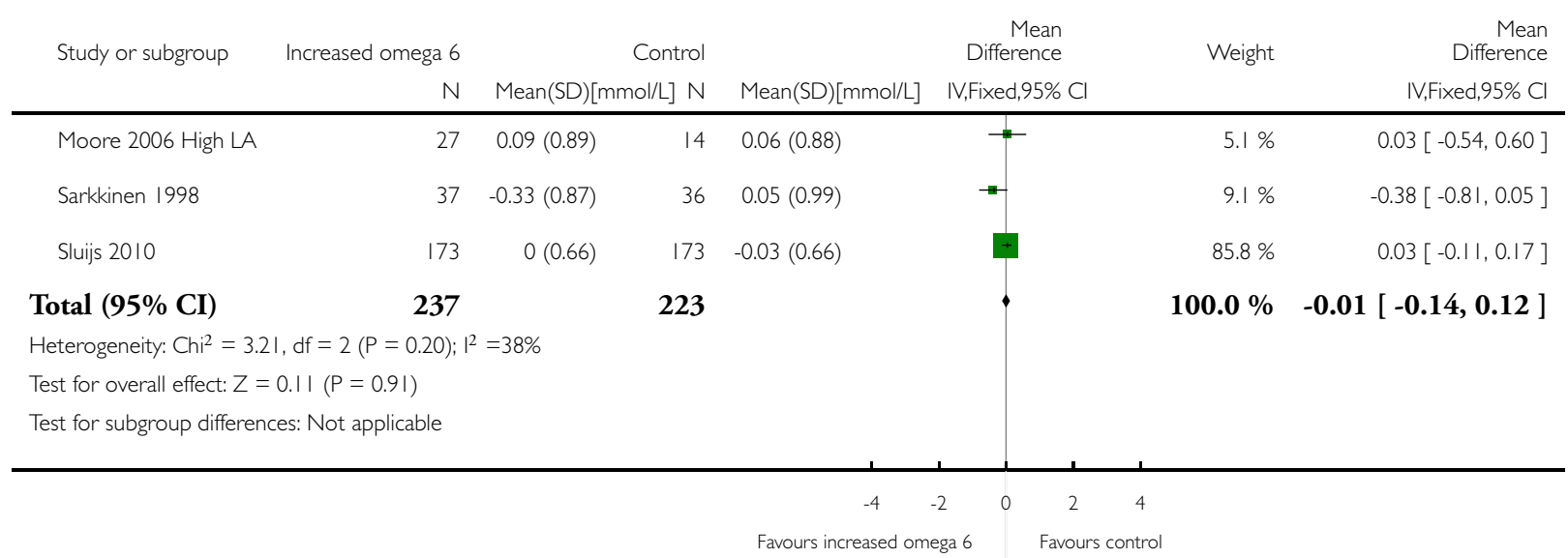


Analysis I.5. Comparison I Increased omega 6 versus control, Outcome 5 HDL cholesterol, change from baseline.

Review: Omega 6 fatty acids for the primary prevention of cardiovascular disease

Comparison: I Increased omega 6 versus control

Outcome: $5 \mathrm{HDL}$ cholesterol, change from baseline

\begin{tabular}{|c|c|c|c|c|c|c|c|}
\hline \multirow[t]{2}{*}{ Study or subgroup } & Favours control & \multicolumn{3}{|c|}{ Control } & $\begin{array}{r}\text { Mean } \\
\text { Difference }\end{array}$ & \multirow[t]{2}{*}{ Weight } & \multirow{2}{*}{$\begin{array}{r}\text { Mean } \\
\text { Difference } \\
\text { IV,Fixed,95\% C }\end{array}$} \\
\hline & $\mathrm{N}$ & Mean(SD) $[\mathrm{mmol} / \mathrm{L}]$ & $\mathrm{N}$ & Mean(SD) $[\mathrm{mmol} / \mathrm{L}]$ & IV,Fixed,95\% Cl & & \\
\hline Moore 2006 High LA & 27 & $-0.01(0.36)$ & 14 & $0.03(0.43)$ & + & $3.7 \%$ & $-0.04[-0.30,0.22]$ \\
\hline Sarkkinen 1998 & 37 & $0.04(0.27)$ & 36 & $0.11(0.39)$ & 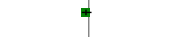 & $10.8 \%$ & $-0.07[-0.22,0.08]$ \\
\hline Sluijs 2010 & 173 & $-0.02(0.26)$ & 173 & $-0.04(0.26)$ & & $85.5 \%$ & $0.02[-0.03,0.07]$ \\
\hline Total (95\% CI) & 237 & & 223 & & , & $100.0 \%$ & $0.01[-0.04,0.06]$ \\
\hline \multicolumn{8}{|c|}{ Heterogeneity: Chi $^{2}=1.29, d f=2(P=0.52) ;\left.\right|^{2}=0.0 \%$} \\
\hline \multicolumn{8}{|c|}{ Test for overall effect: $Z=0.31(P=0.76)$} \\
\hline \multicolumn{8}{|c|}{ Test for subgroup differences: Not applicable } \\
\hline & & & & -4 & -2 & 4 & \\
\hline
\end{tabular}

Analysis I.6. Comparison I Increased omega 6 versus control, Outcome 6 Triglycerides, change from baseline.

Review: Omega 6 fatty acids for the primary prevention of cardiovascular disease

Comparison: I Increased omega 6 versus control

Outcome: 6 Triglycerides, change from baseline

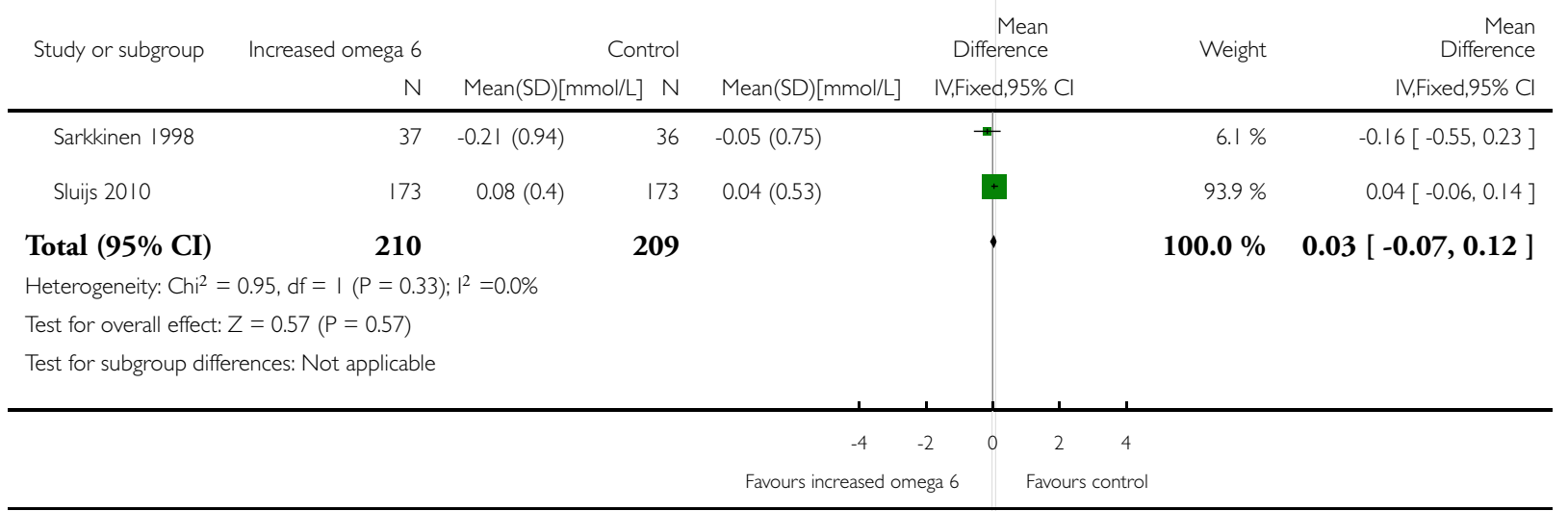

Omega 6 fatty acids for the primary prevention of cardiovascular disease (Review)

Copyright @ 2015 The Cochrane Collaboration. Published by John Wiley \& Sons, Ltd. 
Analysis 2.I. Comparison 2 Reduced omega 6 versus control, Outcome I Systolic blood pressure, change from baseline.

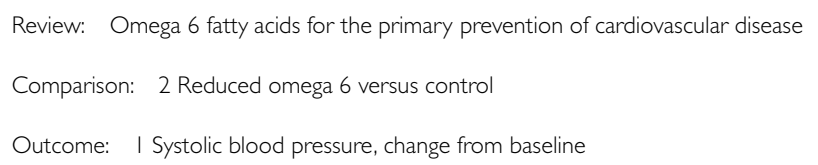

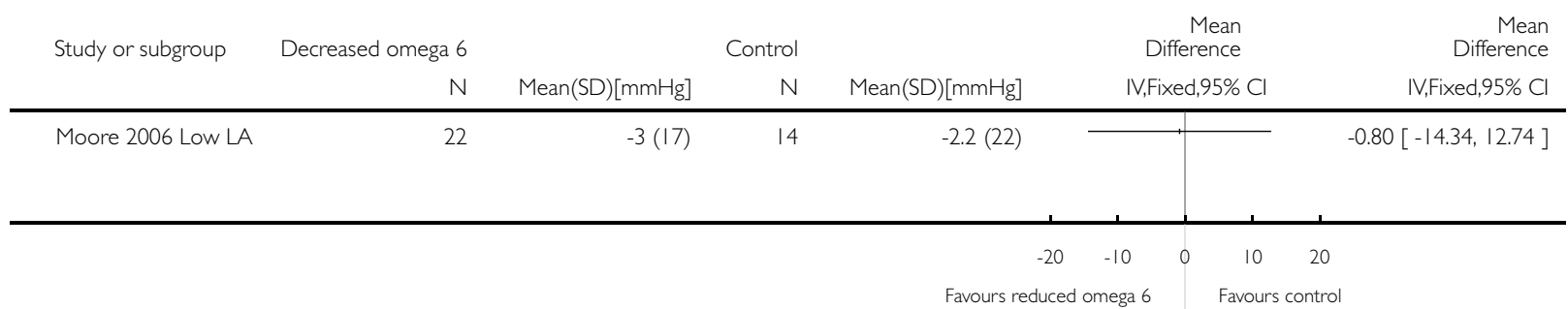

Analysis 2.2. Comparison 2 Reduced omega 6 versus control, Outcome 2 Diastolic blood pressure, change from baseline.

Review: Omega 6 fatty acids for the primary prevention of cardiovascular disease

Comparison: 2 Reduced omega 6 versus control

Outcome: 2 Diastolic blood pressure, change from baseline

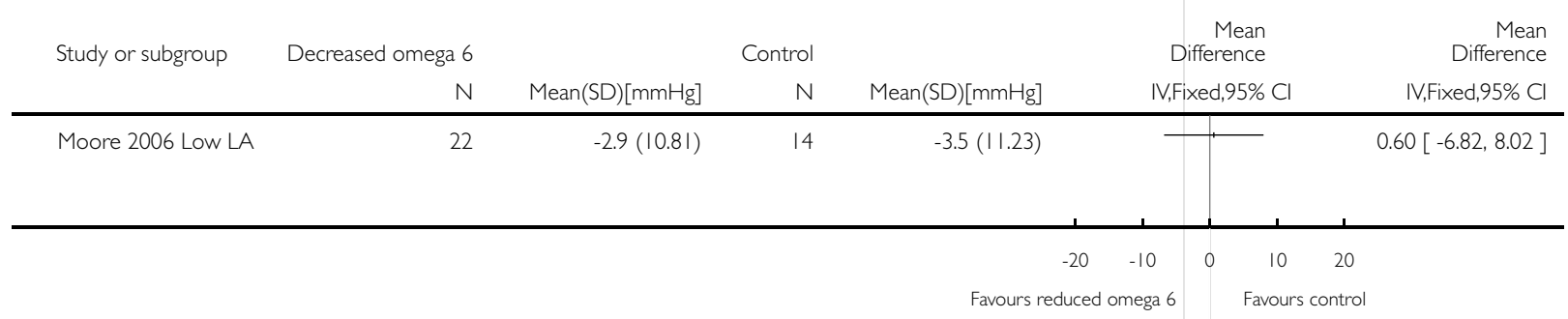


Analysis 2.3. Comparison 2 Reduced omega 6 versus control, Outcome 3 Total cholesterol, change from baseline [mmol/L].

Review: Omega 6 fatty acids for the primary prevention of cardiovascular disease

Comparison: 2 Reduced omega 6 versus control

Outcome: 3 Total cholesterol, change from baseline [mmol/L]

\begin{tabular}{|c|c|c|c|c|c|c|c|}
\hline \multirow[t]{2}{*}{ Study or subgroup } & Decreased omega 6 & \multicolumn{2}{|c|}{ Control } & & $\begin{array}{r}\text { Std. } \\
\text { Mean } \\
\text { Difference }\end{array}$ & \multirow[t]{2}{*}{ Weight } & \multirow{2}{*}{$\begin{array}{r}\text { Std. } \\
\text { Mean } \\
\text { Difference } \\
\text { IV,Fixed,95\% Cl }\end{array}$} \\
\hline & $\mathrm{N}$ & Mean(SD) $[\mathrm{mmol} / \mathrm{L}]$ & $\mathrm{N}$ & $\operatorname{Mean}(\mathrm{SD})[\mathrm{mmol} / \mathrm{L}]$ & IV,Fixed,95\% Cl & & \\
\hline Moore 2006 Low LA & 22 & $-0.08(0.82)$ & 14 & $0.04(0.98)$ & 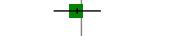 & $30.5 \%$ & $-0.13[-0.80,0.54]$ \\
\hline OPTILIP 2006 & 40 & $-0.04(0.92)$ & 38 & $-0.17(0.92)$ & & $69.5 \%$ & $0.14[-0.30,0.58]$ \\
\hline Total (95\% CI) & 62 & & 52 & & $>$ & $100.0 \%$ & $0.06[-0.31,0.43]$ \\
\hline \multicolumn{8}{|c|}{ Heterogeneity: $\mathrm{Chi}^{2}=0.44, \mathrm{df}=\mathrm{I}(\mathrm{P}=0.5 \mathrm{I}) ; \mathrm{I}^{2}=0.0 \%$} \\
\hline \multicolumn{8}{|c|}{ Test for overall effect: $Z=0.30(P=0.76)$} \\
\hline \multicolumn{8}{|c|}{ Test for subgroup differences: Not applicable } \\
\hline & & & & -4 & -2 & 4 & \\
\hline & & & & Favours reduced on & lega 6 & trol & \\
\hline
\end{tabular}

Analysis 2.4. Comparison 2 Reduced omega 6 versus control, Outcome 4 LDL cholesterol, change from baseline.

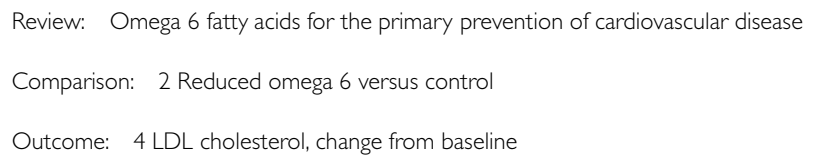

\begin{tabular}{|c|c|c|c|c|c|c|c|c|}
\hline \multirow[t]{2}{*}{ Study or subgroup } & Decreased omega 6 & \multicolumn{2}{|c|}{ Control } & \multicolumn{2}{|r|}{$\begin{array}{r}\text { Mean } \\
\text { Difference }\end{array}$} & \multicolumn{2}{|r|}{ Weight } & \multirow{2}{*}{$\begin{array}{r}\text { Mean } \\
\text { Difference } \\
\text { IV,Fixed,95\% Cl }\end{array}$} \\
\hline & $\mathrm{N}$ & $\operatorname{Mean}(\mathrm{SD})[\mathrm{mmol} / \mathrm{L}]$ & $\mathrm{N}$ & Mean(SD)[mmol/L] & IV,Fixed,95\% & $\mathrm{Cl}$ & & \\
\hline Moore 2006 Low LA & 22 & $-0.12(0.77)$ & 14 & $0.06(0.88)$ & 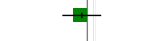 & & $34.3 \%$ & $-0.18[-0.74,0.38]$ \\
\hline OPTILIP 2006 & 40 & $-0.13(0.92)$ & 38 & $-0.17(0.91)$ & + & & $65.7 \%$ & $0.04[-0.37,0.45]$ \\
\hline Total (95\% CI) & 62 & & 52 & & $\bullet$ & & $100.0 \%$ & $-0.04[-0.36,0.29]$ \\
\hline \multicolumn{9}{|c|}{ Heterogeneity: $\mathrm{Chi}^{2}=0.39, \mathrm{df}=\mathrm{I}(\mathrm{P}=0.53) ; \mathrm{I}^{2}=0.0 \%$} \\
\hline \multicolumn{9}{|c|}{ Test for overall effect: $Z=0.21(P=0.83)$} \\
\hline \multicolumn{9}{|c|}{ Test for subgroup differences: Not applicable } \\
\hline & & & & -4 & -2 & 4 & & \\
\hline \multicolumn{9}{|c|}{ Favours reduced omega 6} \\
\hline
\end{tabular}




\section{Analysis 2.5. Comparison 2 Reduced omega 6 versus control, Outcome 5 HDL cholesterol, change from}

baseline.

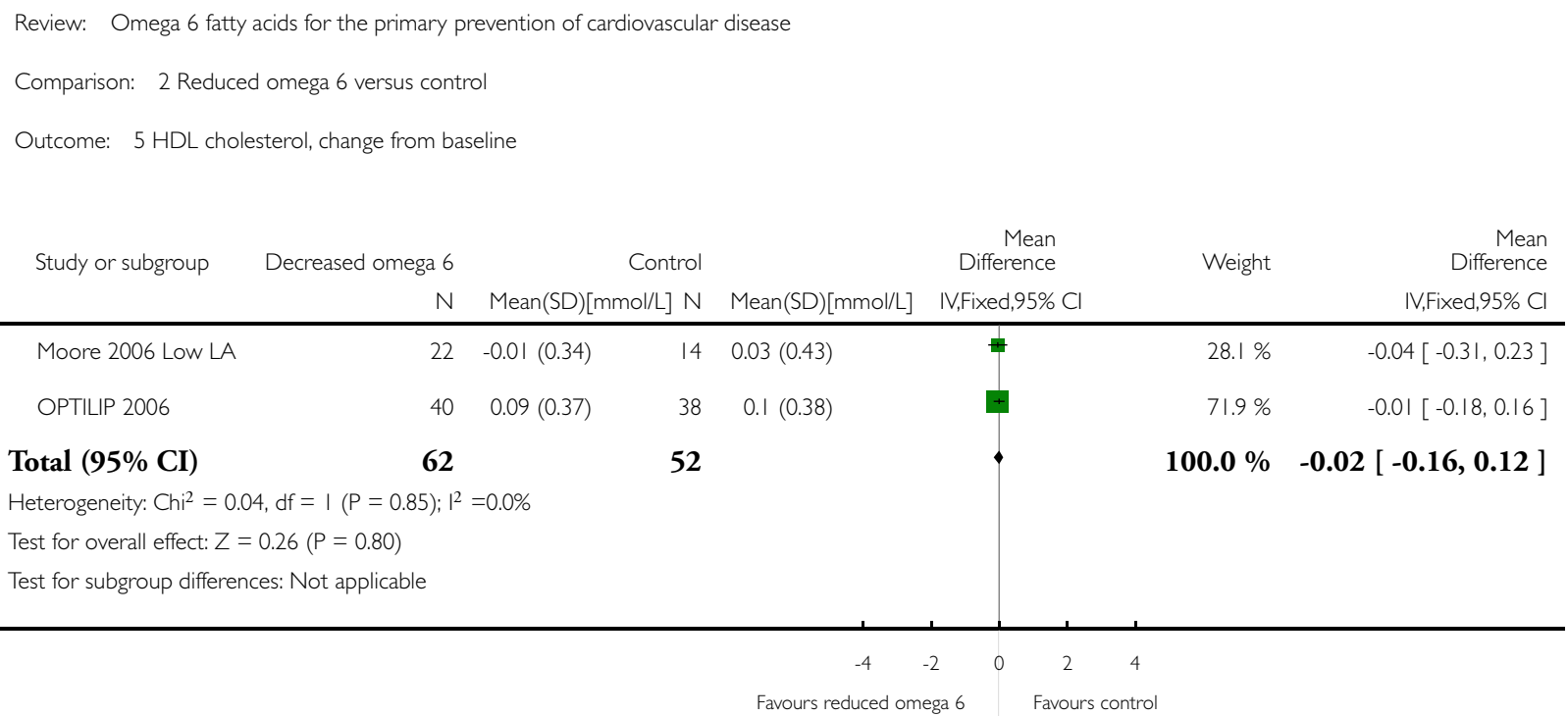


Analysis 2.6. Comparison 2 Reduced omega 6 versus control, Outcome 6 Triglycerides, change from baseline.

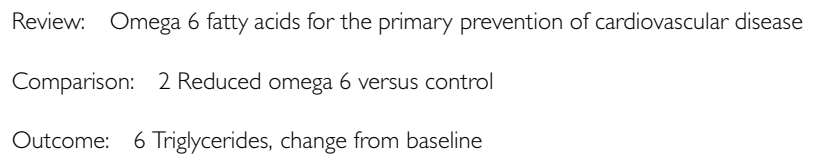

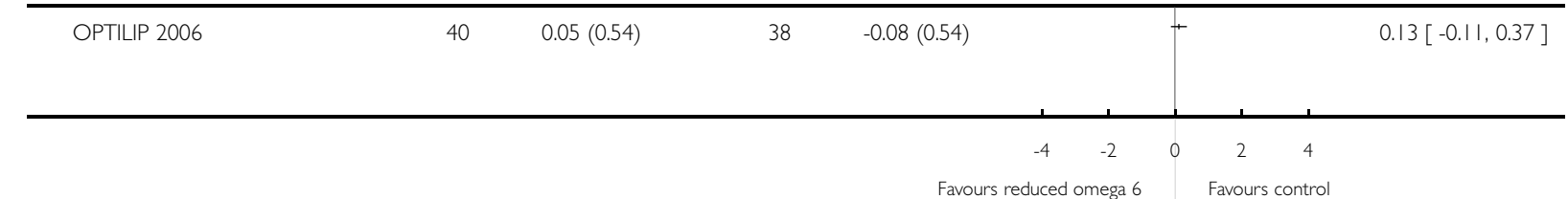

\section{A P P E N D I C ES}

\section{Appendix I. Search strategies}

\section{The Cochrane Library}

\#1MeSH descriptor: [Fatty Acids, Omega-6] this term only

\#2"omega 6"

\#3(n-6 near/4 acid*)

\#4(“n 6" near/4 acid*)

\#5omega-6

\#6"linoleic acid*"

\#7(poly* near/4 unsat* near/4 fatty acid*)

\#8PUFA

\#9MeSH descriptor: [Dietary Fats, Unsaturated] this term only

\#10MeSH descriptor: [Corn Oil] this term only

\#11((corn or maize or mazola) near/4 oil $\left.{ }^{*}\right)$

\#12maydol

\#13lipomul*

$\# 14 \mathrm{MeSH}$ descriptor: [Cottonseed Oil] this term only

\#15 cottonseed*

\#16 “cotton seed*”

\#17MeSH descriptor: [Soybean Oil] this term only

\#18intralipid or nutrilipid

\#19((soy bean or soybean) near/4 (oil* or fat* or sauce*))

\#20(so?a near/4 oil*)

\#21so?aoil* 
\#22(soy near/4 oil*)

\#23soyacal or travamulsion

\#24(sunflower near/4 oil*)

\#25helianth*

\#26MeSH descriptor: [Safflower Oil] this term only

\#27(safflower near/4 oil*) .tw.

\#28liposyn

\#29(grapeseed near/4 oil ${ }^{*}$ )

$\# 30 \# 1$ or $\# 2$ or \#3 or \#4 or \#5 or \#6 or \#7 or \#8 or \#9 or \#10 or \#11 or \#12 or \#13 or \#14 or \#15 or \#16 or \#17 or \#18 or \#19 or \#20

or \#21 or \#22 or \#23 or \#24 or \#25 or \#26 or \#27 or \#28 or \#29

$\# 31 \mathrm{MeSH}$ descriptor: [Cardiovascular Diseases] explode all trees

\#32 cardio*

\#33cardia*

\#34heart*

\#35 coronary*

\#36angina*

\#37ventric*

\#38myocard*

\#39pericard*

\#40isch?em*

\#41emboli*

\#42arrhythmi*

\#43thrombo*

\#44atrial next fibrillat*

\#45 tachycardi*

\#46endocardi*

\#47(sick next sinus)

\#48MeSH descriptor: [Stroke] explode all trees

$\# 49$ (stroke or stokes)

\#50 cerebrovasc*

\#51cerebral next vascular

\#52apoplexy

\#53(brain near/2 accident*)

\#54((brain* or cerebral or lacunar) near/2 infarct*)

\#55MeSH descriptor: [Hypertension] explode all trees

\#56hypertensi*

\#57(peripheral next arter* next disease*)

\#58((high or increased or elevated) near/2 blood pressure)

\#59MeSH descriptor: [Hyperlipidemias] explode all trees

\#60hyperlipid*

\#61 hyperlip?emia*

\#62 hypercholesterol $^{*}$

\#63hypercholester?emia*

\#64hyperlipoprotein?emia*

\#65hypertriglycerid?emia*

\#66MeSH descriptor: [Arteriosclerosis] explode all trees

\#67MeSH descriptor: [Cholesterol] explode all trees

\#68cholesterol

\#69 “coronary risk factor*”

\#70MeSH descriptor: [Blood Pressure] this term only

\#71"blood pressure"

Omega 6 fatty acids for the primary prevention of cardiovascular disease (Review) 
$\# 72 \# 31$ or \#32 or \#33 or \#34 or \#35 or \#36 or \#37 or \#38 or \#39 or \#40 or \#41 or \#42 or \#43 or \#44 or \#45 or \#46 or \#47 or \#48 or $\# 49$ or \#50 or \#51 or \#52 or \#53 or \#54 or \#55 or \#56 or \#57 or \#58 or \#59 or \#60 or \#61 or \#62 or \#63 or \#64 or \#65 or \#66 or \# 67 or \#68 or \#69 or \#70 or \#71

$\# 73 \# 30$ and $\# 72$

\section{MEDLINE}

1. Fatty Acids, Omega-6/

2. omega 6.tw.

3. (n-6 adj 4 acid $\left.{ }^{*}\right)$.tw.

4. (n 6 adj4 acid $\left.^{*}\right)$.tw.

5. omega-6.tw.

6. linoleic acid*.tw.

7. (poly* adj4 unsat* adj4 fatty acid*).tw.

8. PUFA.tw.

9. Dietary Fats, Unsaturated/

10. corn oil/

11. ((corn or maize or mazola) adj4 oil $\left.^{*}\right)$.tw.

12. maydol.tw.

13. lipomul*.tw.

14. cottonseed oil/

15. cottonseed*.tw.

16. cotton seed*.tw.

17. soybean oil/

18. intralipid.tw.

19. nutrilipid.tw.

20. ((soy bean or soybean) adj4 (oil* or fat* or sauce*)).tw.

21. (so?a adj4 oil $\left.{ }^{*}\right)$.tw.

22. so?aoil*.tw.

23. (soy adj4 oil*).tw.

24. soyacal.tw.

25. travamulsion.tw.

26. (sunflower adj4 oil*).tw.

27. helianth*.tw.

28. Safflower Oil/

29. (safflower adj4 oil*).tw.

30. liposyn.tw.

31. (grapeseed adj4 oil*).tw.

32. or/1-31

33. exp Cardiovascular Diseases/

34. cardio*.tw.

35. cardia*.tw.

36. heart*.tw.

37. coronary*.tw.

38. angina*.tw.

39. ventric*.tw.

40. myocard*.tw.

41. pericard*.tw.

42. isch?em*.tw.

43. emboli*.tw.

44. arrhythmi*.tw.

45. thrombo*.tw.

46. atrial fibrillat*.tw.

Omega 6 fatty acids for the primary prevention of cardiovascular disease (Review)

Copyright $\odot 2015$ The Cochrane Collaboration. Published by John Wiley \& Sons, Ltd. 
47. tachycardi*.tw.

48. endocardi*.tw.

49. (sick adj sinus).tw.

50. exp Stroke/

51. (stroke or stokes).tw.

52. cerebrovasc*.tw.

53. cerebral vascular.tw.

54. apoplexy.tw.

55. (brain adj2 accident*).tw.

56. ((brain* or cerebral or lacunar) adj2 infarct*).tw.

57. exp Hypertension/

58. hypertensi*.tw.

59. peripheral arter* disease*.tw.

60. ((high or increased or elevated) adj2 blood pressure).tw.

61. exp Hyperlipidemias/

62. hyperlipid*.tw.

63. hyperlip?emia*.tw.

64. hypercholesterol*.tw.

65. hypercholester?emia*.tw.

66. hyperlipoprotein?emia*.tw.

67. hypertriglycerid?emia*.tw.

68. exp Arteriosclerosis/

69. exp Cholesterol/

70. cholesterol.tw.

71. "coronary risk factor* ".tw.

72. Blood Pressure/

73. blood pressure.tw.

74. or/33-73

75.32 and 74

76. randomized controlled trial.pt.

77. controlled clinical trial.pt.

78. randomized.ab.

79. placebo.ab.

80. drug therapy.fs.

81. randomly.ab.

82. trial.ab.

83. groups.ab.

84.76 or 77 or 78 or 79 or 80 or 81 or 82 or 83

85. exp animals/ not humans.sh.

86. 84 not 85

87.75 and 86

\section{EMBASE}

1. omega 6 fatty acid/

2. omega 6.tw.

3. (n-6 adj 4 acid*).tw.

4. (n 6 adj4 acid $\left.^{*}\right)$.tw.

5. omega-6.tw.

6. linoleic acid*.tw.

7. (poly* adj4 unsat* adj4 fatty acid*).tw.

8. PUFA.tw.

9. edible oil/

Omega 6 fatty acids for the primary prevention of cardiovascular disease (Review)

Copyright $\odot 2015$ The Cochrane Collaboration. Published by John Wiley \& Sons, Ltd. 
10. corn oil/

11. ((corn or maize or mazola) adj4 oil $\left.{ }^{*}\right)$.tw.

12. maydol.tw.

13. lipomul*.tw.

14. cotton seed oil/

15. cottonseed*.tw.

16. cotton seed*.tw.

17. soybean oil/

18. intralipid.tw.

19. nutrilipid.tw.

20. ((soy bean or soybean) adj4 (oil* or fat* or sauce*)).tw.

21. (so?a adj4 oil $\left.{ }^{*}\right)$.tw.

22. so?aoil*.tw.

23. (soy adj4 oil*).tw.

24. soyacal.tw.

25. travamulsion.tw.

26. sunflower oil/

27. (sunflower adj4 oil*).tw.

28. helianth*.tw.

29. safflower oil/

30. (safflower adj4 oil).tw.

31. liposyn.tw.

32. (grapeseed adj4 oil*).tw.

33. or/1-32

34. exp cardiovascular disease/

35. cardio*.tw.

36. cardia*.tw.

37. heart*.tw.

38. coronary*.tw.

39. angina*.tw.

40. ventric*.tw.

41. myocard*.tw.

42. pericard $^{*}$.tw.

43. isch?em*.tw.

44. emboli*.tw.

45. arrhythmi*.tw.

46. thrombo*.tw.

47. atrial fibrillat*.tw.

48. tachycardi*.tw.

49. endocardi*.tw.

50. (sick adj sinus).tw.

51. exp cerebrovascular disease/

52. (stroke or stokes).tw.

53. cerebrovasc ${ }^{*}$.tw.

54. cerebral vascular.tw.

55. apoplexy.tw.

56. (brain adj2 accident*).tw.

57. ((brain* or cerebral or lacunar) adj2 infarct*).tw.

58. exp hypertension/

59. hypertensi*.tw.

60. peripheral arter* disease*.tw.

61. ((high or increased or elevated) adj2 blood pressure).tw.

62. exp hyperlipidemia/

Omega 6 fatty acids for the primary prevention of cardiovascular disease (Review)

Copyright $\odot 2015$ The Cochrane Collaboration. Published by John Wiley \& Sons, Ltd. 
63. hyperlipid*.tw.

64. hyperlip?emia*.tw.

65. hypercholesterol*.tw.

66. hypercholester?emia*.tw.

67. hyperlipoprotein?emia*.tw.

68. hypertriglycerid?emia*.tw.

69. exp Arteriosclerosis/

70. exp Cholesterol/

71. cholesterol.tw.

72. "coronary risk factor*”.tw.

73. Blood Pressure/

74. blood pressure.tw.

75. or/34-74

76. 33 and 75

77. random\$.tw.

78. factorial\$.tw.

79. crossover\$.tw.

80. cross over\$.tw.

81. cross-over\$.tw.

82. placebo $\$ . t w$.

83. (doubl\$ adj blind\$).tw.

84. (singl\$ adj blind $\$$ ).tw.

85. assign \$.tw.

86. allocat $\$ . t w$.

87. volunteer\$.tw.

88. crossover procedure/

89. double blind procedure/

90. randomized controlled trial/

91. single blind procedure/

92.77 or 78 or 79 or 80 or 81 or 82 or 83 or 84 or 85 or 86 or 87 or 88 or 89 or 90 or 91

93. (animal/ or nonhuman/) not human/

94.92 not 93

95.76 and 94

96. limit 95 to embase

\section{Web of Science}

\# 19 \#18 AND \#17

\# $18 \mathrm{TS}=\left(\right.$ random* $^{*}$ or blind* or allocat* or assign* or trial* or placebo* or crossover* or cross-over*)

\# 17 \#16 AND \#8

\# 16 \#15 OR \#14 OR \#13 OR \#12 OR \#11 OR \#10 OR \#9

\# 15 TS=(hyperlipid* OR hyperlip?emia* OR hypercholesterol* OR hypercholester?emia* OR hyperlipoprotein?emia* OR hypertriglycerid?emia*)

\# 14 TS=("high blood pressure")

\# 13 TS=(hypertensi* OR "peripheral arter* disease*”)

\# 12 TS=(stroke OR stokes OR cerebrovasc* OR cerebral OR apoplexy OR (brain SAME accident*) OR (brain SAME infarct*))

\# 11 TS=(“atrial fibrillat*” OR tachycardi* OR endocardi*)

\# 10 TS=(pericard* OR isch?em* OR emboli* OR arrhythmi* OR thrombo*)

\# 9 TS=(cardio* OR cardia* OR heart* OR coronary* OR angina* OR ventric* OR myocard*)

\# 8 \#7 OR \#6 OR \#5 OR \#4 OR \#3 OR \#2 OR \#1

\# $7 \mathrm{TS}=\left(\left(\right.\right.$ grapeseed near $/ 4$ oil $\left.\left.^{*}\right)\right)$

\# 6 TS=((safflower N4 oil $\left.{ }^{*}\right)$ or liposyn $)$

\# 5 TS=((sunflower N4 oil*) or helianth*)

Omega 6 fatty acids for the primary prevention of cardiovascular disease (Review)

Copyright @ 2015 The Cochrane Collaboration. Published by John Wiley \& Sons, Ltd. 
\# 4 TS=(((soy bean or soybean) N4 (oil* or fat* or sauce*)) or (so?a N4 oil*) or intralipid or nutrilipid or so?aoil ${ }^{*}$ or (soy near/4 oil*) or soyacal or travamulsion)

\# 3 TS=(cottonseed* or "cotton seed*")

\# 2 TS=(((corn or maize or mazola) N4 oil $\left.^{*}\right)$ or maydol or lipomul*)

\# 1 TS=("omega 6" or "omega-6" or (n-6 N4 acid*) or ("n 6" N4 acid*) or "linoleic acid*” or (poly* N4 unsat* N4 fatty acid*) or PUFA)

\section{Clinical trial registers}

Omega 6 and Cardio*

Omega 6 and primary prevention OR risk AND Cardio*

Omega 6

\section{CONTRIBUTIONS OFAUTHORS}

LHo, KR, and LH contributed to the protocol development. LH, CC, and NF screened titles and abstracts and assessed studies for inclusion and exclusion. LA, LH, and CC extracted data and assessed methodological rigour. Analyses were conducted by LA and checked by KR. LH wrote the first draft of the review, which was updated by LA and KR.

\section{DECLARATIONSOF INTEREST}

LA: None known

LH: None known

CC: None known

NF: None known

LHo: None known

KR: None known

\section{SOURCES OF SUPPORT}

\section{Internal sources}

- Warwick Medical School, University of Warwick, UK.

\section{External sources}

- NIHR Cochrane Programme Grant, UK.

- Karen Rees and Lena AlKhudairy are also supported by the National Institute for Health Research (NIHR) Collaboration for Leadership in Applied Health Research and Care West Midlands at University Hospitals Birmingham NHS Foundation Trust, UK. 


\section{DIFFERENCES BETWEEN PROTOCOLANDREVIEW}

We did not search AMED, as initially planned in Hartley 2014, because of lack of resources. 